\title{
1 Functional analysis of the chromosomal passenger complex in
}

\section{Arabidopsis}

3

4 Shinichiro Komaki ${ }^{1,2}$, Hidenori Takeuchi ${ }^{3,4}$, Yuki Hamamura², Maren Heese ${ }^{2}$, Takashi

5 Hashimoto $^{1}$, and Arp Schnittger ${ }^{2, *}$

6

$7 \quad$ Key words: Cell division, spindle assembly checkpoint, phragmoplast, Aurora B

8

$9{ }^{1}$ Nara Institute of Science and Technology, Graduate School of Biological Sciences,

8916-5 Takayama, Ikoma, Nara 630-0192, Japan

112 University of Hamburg, Institute for Plant Sciences and Microbiology, Department

12 of Developmental Biology, Ohnhorststr. 18, D-22609 Hamburg, Germany

$13{ }^{3}$ Institute of Transformative Bio-Molecules (WPI-ITbM), Nagoya University, Furo-

14 cho, Chikusa-ku, Nagoya, Aichi 464-8601, Japan.

154 Institute for Advanced Research, Nagoya University, Furo-cho, Chikusa-ku,

16 Nagoya, Aichi 464-8602, Japan

17 *For correspondence arp.schnittger@uni-hamburg.de, Phone: +49 4042816 502,

18 Fax: +494042816503 


\section{SUMMARY}

A key regulator of cell division in all eukaryotes is the kinase Aurora B, which is encoded by the Aurora 3 (AUR3) gene in Arabidopsis. Aurora B has at least two central functions during cell division. On the one hand, it is essential for the correct, i.e. balanced, segregation of chromosomes in mitosis and meiosis by controlling kinetochore function. On the other hand, Aurora B acts at the division plane, where it is necessary to complete cytokinesis. To accomplish these two spatially distinct functions, Aurora B in animals is guided to its sites of action by Borealin, INCENP, and Survivin that build together with Aurora B the chromosome passenger complex (CPC). However, besides Aurora homologs, only a candidate gene with restricted homology to INCENP has so far been described in Arabidopsis raising the question whether there exists a full complement of the $\mathrm{CPC}$ in plants and how Aurora homologs are targeted subcellularly. Here, we have identified and functionally characterized a Borealin homolog, BOREALIN RELATED (BORR), in

33 Arabidopsis. This, together with detailed localization studies including the putative

34 Arabidopsis INCENP homolog, supports the existence of a CPC in plants. 


\section{INTRODUCTION}

36 Equal chromosome segregation during cell division is crucial for survival, growth,

37 and reproduction of every organism. Chromosome segregation is assured by the M-

38 phase checkpoint, which involves two regulatory units, the spindle assembly

39 checkpoint (SAC) and the chromosomal passenger complex (CPC) (Carmena et al.,

40 2012).

41 Chromatids are held together by Cohesin, a proteinaceous ring-like

42 structure, which needs to be cleaved by Separase to allow their separation in anaphase. The SAC inhibits the Anaphase Promoting Complex/Cyclosome (APC/C),

an E3 ubiquitin ligase, which mediates the degradation of Securin, an inhibitor of

Separase, until all kinetochores are properly attached to microtubules of opposing

poles (London and Biggins, 2014; Komaki and Schnittger, 2016).

The CPC has been well characterized in yeast and mammals, where it has

been found to consist of four proteins: Aurora kinase B (Aurora B), Borealin, Inner

centromere protein (INCENP), and Survivin. The CPC fulfills several functions

during mitosis. In particular, it is involved in ensuring that all kinetochores are

51 attached to microtubules emanating from opposing poles (Kitagawa and Lee,

52 2015). The CPC localizes to inner centromere where it activates Aurora B in 
53 response to low inter-kinetochore tension. Active Aurora B phosphorylates

54 kinetochore proteins leading to the destabilization of erroneous microtubule

55 attachments. Once proper kinetochore-microtubule attachments are established

56 from opposing poles, which gives high inter-kinetochore tension, Aurora B is

57 spatially separated from kinetochores resulting in proper bistable spindle

58 formation.

Aurora B belongs to the Aurora kinase family of serine/threonine kinases that

60 are highly conserved in the eukaryotic kingdom (van der Waal et al., 2012; Weimer et al., 2016). While yeast possesses a single Aurora homolog, mammals have three

62 Aurora kinases, Aurora A, Aurora B, and Aurora C, among which only Aurora C acts in meiosis (Goldenson and Crispino, 2015). Since these three kinases share a common consensus phosphorylation motif, it is thought that interacting proteins are important for their localization and substrate specificity. spindle microtubules to regulate spindle assembly (Gruss and Vernos, 2004). In contrast, Aurora B and Aurora C, the catalytic subunit of the CPC, is involved in the correction of erroneous kinetochore-microtubule attachments, activation of the 
71 its dynamic localization pattern controlled by the three non-catalytic subunits of the CPC (van der Horst and Lens, 2014). yeast directly binds to all other components of the complex. Borealin and Survivin interact with the conserved N-terminal region of INCENP while Aurora B binds to the C-terminal domain of INCENP, called IN-box (Carmena et al., 2012). The IN-box is required for interaction with and activation of Aurora B (Honda et al., 2003). While the N-terminus of Borealin acts as the INCENP-binding region its Cterminus contains a homo-dimerization domain that is involved in a stable CPC localization at centromeres (Bekier et al., 2015). In addition, the phosphorylation status of the central part affects the centromere localization and steady-state level of Borealin itself (Kaur et al., 2010; Date et al., 2012). Aurora kinases in plants are categorized into two groups, alpha-Aurora and beta-Aurora, based on the localization pattern and sequences (Weimer et al., 2016). Interestingly, these two groups have mixed features of the animal Aurora A and Aurora B/C groups. For instance, AUR1 and AUR2 in Arabidopsis, both belonging to the alpha class, localize to spindle microtubules, which is reminiscent of Aurora A, but they also localize to the central region of phragmoplasts 
paralleling Aurora B/C at the cell cleavage site. AUR3, a member of the beta-Aurora

group, localizes to kinetochores, similar to Aurora B (Komaki and Schnittger, 2017),

91 but in contrary to Aurora B, it does not accumulate at the division plane (Demidov et al., 2005).

While aur1 and aur2 single mutants do not show any obvious growth alterations, the aur1 aur2 double null mutant is gametophytic lethal (Van Damme et al., 2011). A weak loss-of-function aur1 aur2 double mutant exhibits altered division plane orientation, reduced pollen viability, and enhanced vascular cell differentiation. These defects can be rescued by expressing either AUR1 or AUR2 but not AUR3, indicating that alpha-Auroras and beta-Auroras have distinct functions (Van Damme et al., 2011; Demidov et al., 2014; Lee et al., 2019). $\mathrm{CPC}$, it is not even clear whether there is a conserved CPC function in plants. The unknown function, which is conserved only in plants. Although Arabidopsis incenp mutants, also known as wyrd (wyr), show defects in gametophytic cell division (Kirioukhova et al., 2011), it is still unclear whether Arabidopsis INCENP acts as 
107 and binding partners.

108 Here, we present the identification and functional characterization of an

109 Arabidopsis Borealin homolog, which colocalizes with the INCENP homolog to the

110 inner centromere and the central domain of the phragmoplast. We also observed

111 that only AUR3 acts as the catalytic subunit of the plant CPC. These data

112 underscore the mixed features of plant Aurora kinases. 


\section{RESULTS}

\section{Identification of a putative Borealin homolog in plants}

117 As a first step to determine whether plants have a functional CPC, we searched for

118 Borealin and Survivin homologs in the Arabidopsis genome. Given that the putative

119 INCENP homolog of Arabidopsis, WYR, shares only very weak similarities with its

120 animal counterpart (Kirioukhova et al., 2011), we expected the same to be the case

121 for Borealin and Survivin. Indeed, standard BLAST searches did not result in the

122 identification of likely candidates. Therefore, we made use of the fact that Borealin

123 is transcriptionally controlled by the tumor suppressor protein Retinoblastoma in

124 animals (Cam et al., 2004; Date et al., 2007). Mining a dataset of the genome-wide

125 binding sites of the Arabidopsis Retinoblastoma homolog RETINOBLASTOMA-

126 RELATED (RBR1), revealed several unknown genes likely involved in cell division

127 control (Bouyer et al., 2018) (Sup Fig. 1). One of these genes, AT4G39630, showed a

128 weak similarity to Borealin and will be referred to as BOREALIN-RELATED (BORR)

129 (Supplemental Fig. S1A).

130 The C-terminal region of the corresponding protein shows $37 \%$ similarity

131 with the central region of human Borealin, which includes highly conserved 132 consensus sites for CDK phosphorylation (Fig. 1A). A second stretch of homology 
133 can be found in the N-terminus, which is predicted to adopt an alpha-helical

134 structure. In animals and yeast this N-terminal alpha-helix forms a three-helical

135 bundle with INCENP and Survivin (Fig. 1A) (Jeyaprakash et al., 2007). Notably, the

136 Arabidopsis BORR is considerably shorter than the human homolog (233 aa versus

137280 aa), partly as the result of a truncated C-terminal domain. Using BORR as a

138 template, we found putative Borealin genes in all branches of the plant kingdom,

139 including angiosperms, gymnosperms, pteridophytes, bryophytes, and algae (Fig.

$1401 \mathrm{~B}$ - phylogenetic tree).

\section{Phenotypic analysis of borr mutants}

143 Since no mutants for BORR were available in the public mutant collections of

144 Arabidopsis, we generated a mutant by CRISPR/Cas9. The resulting borr-1 allele

145 has a $\mathrm{T}$ insertion in the $2^{\text {nd }}$ exon, i.e. between nucleotides 280 and 281 downstream

146 of the start codon leading to a stop codon and a predicted truncated protein of 67

147 amino acids (Supplemental Fig. S1A). While the heterozygous borr-1 plants grow as

148 the wildtype, we could never obtain homozygous mutant plants. Consistently, we

149 observed aborted seeds and undeveloped ovules in siliques of borr-1 +/- (Fig.

$1502 \mathrm{~A}, \mathrm{~B})$. 
mutation in the BORR gene, we constructed reporter lines in which the genomic

loss of BORR affects plant reproduction.

used borr-1 +/- as male parent, the transmission rate was determined to be $44 \%$.

160 Consistently, 96\% of borr1+/- pollen resembled wild-type pollen and based on

DAPI-staining, contained two sperm cells.

rate was reduced to $29 \%$, indicating that $B O R R$ is especially needed for the

165 the mature female gametophyte no obvious developmental defects were observed suggesting that the reduced transmission of borr-1 through the female 
169 aborted seeds when we used borr $-1+/-$ as the female $(n=250)$ in contrast to $3 \%$

170 unfertilized ovules/early arrested seeds and $0.3 \%$ late aborted seeds in control

171 crosses when we used the wildtype as the female and male parent ( $n=299)$ (Fig.

$1722 \mathrm{~A}, \mathrm{~B})$.

In addition, we observed abnormal embryo development, including

174 delayed and distorted embryos or embryo-like structures in approximately $10 \%$ of

175 all ovules/seeds analyzed when borr-1+/- was used as the female parent in crosses

176 with the wildtype as a male versus $4 \%$ in the control crosses supporting a female

177 gametophytic effect of borr ( $\mathrm{n}=313$ and $\mathrm{n}=408$ for the control cross) (Fig. 2C,D).

178 One likely explanation for this is that the divisions leading to the development of

179 the embryo sac cause aneuploidy in borr that preclude and/or severely interfere

180 with embryo development.

181 In addition, $B O R R$ is needed during embryo development since the number

182 of seeds with embryonic defects almost doubled in self-fertilized borr-1 mutants

183 (Fig. 2D). Thus, BORR is an essential gene needed for cell proliferation and

184 development during early stages of the plant life cycle.

To address the BORR function after embryo development, we generated 
targeted against the $2^{\text {nd }}\left(\operatorname{amiBORR\# 1)}\right.$ and $3^{\text {rd }}$ exon (amiBORR\#2) of BORR,

analyses, we selected two transgenic plants for each construct (amiBORR\#1-1,

192 similar level of BORR transcript reduction (Fig. 3B) and had a dwarf phenotype

194 flowering stage, all BORR knockdown plants were bushy and exhibited a typical

bonsai phenotype (sometimes also called broom stick phenotype), which is

Zheng et al., 2011).

201 (Fig. 3C and D). Microscopic analyses of amiBORR\#1-1 revealed that the root 
epidermal, cortex and endodermal layers underlining that BORR is required for

proper cell division (Fig. 3E).

segregation as well, amiBORR\#1-1 was introgressed into a transgenic line

210 (Komaki and Schnittger, 2017). Indeed, we could frequently observe lagging

211 chromosomes in amiBORR\#1-1 plant cells (9 out of 50), a phenotype that hardly

212 occurred in the wildtype control plant cells (1 out of 50 ) (Fig. $3 \mathrm{H}$ and I). To

213 examine whether the lagging chromosomes are related to a compromised AUR3

214 localization, we introduced a previously generated AUR3:GFP reporter into amiBORR\#1-1 plants (Komaki and Schnittger, 2017). While some AUR3:GFP signal

217 intensity was much weaker than in wild-type plants, suggesting that Arabidopsis

218 BORR ensures chromosome segregation through AUR3 localization (Fig. 3J and K).

219 Taken together, corresponding to Borealin function in animals, BORR is required for proper chromosome segregation and cell division in Arabidopsis. 
223 To reveal the molecular network of the Arabidopsis CPC, we investigated the

224 interaction of BORR with INCENP and the three Aurora kinases of Arabidopsis.

225 Although Borealin has a conserved coiled-coil domain, which is known as an

226 INCENP binding site in other organisms (Jeyaprakash et al., 2007), an interaction

227 between BORR and INCENP was not detected by a yeast two-hybrid interaction

assay (Y2H assay) (Fig. 4A). We next performed an in vivo co-immunoprecipitation

229 (IP) assay. To this end, anti-GFP immuno-precipitates from total protein extracts of

230 plants expressing both BORR:RFP and GFP:INCENP or from plants expressing

231 BORR:RFP and free GFP as a negative control were probed with an anti-RFP

232 antibody. BORR:RFP was only detected in the extract of plants co-expressing GFP-

233 INCENP, indicating that Arabidopsis BORR could be part of a CPC in vivo (Fig. 4C).

234 Consistent with the topology of the CPC in animal and yeast, we further

235 found that INCENP interacts specifically with AUR3 through its C-terminal region

236 while no interaction was detected with AUR1 or AUR2 (Fig. 4A, B). The C-terminal

237 region of INCENP contains an Aurora B binding domain, called IN-box, which is

238 conserved from yeast to mammals (Adams et al., 2000). Since Arabidopsis INCENP

239 also possesses a putative IN-box in its C-terminus, we exchanged Trp1723 to Gly

240 and Phe1745 to Ala. These residues are conserved in yeast and animals, and the 
241 Trp1723 mutation leads to loss of interaction with Aurora B in in vitro assays

242 (Sessa et al., 2005), as well as in chicken culture cells (Xu et al., 2009). Consistent

243 with a key role of the putative IN-box, Arabidopsis INCENPF1745A partially and

244 INCENPW1723G completely failed to interact with AUR3 (Fig. 4B).

246 Expression pattern and subcellular localization of the CPC components in

247 mitosis

248 To investigate the spatial and temporal expression pattern of $B O R R$, we generated

249 transgenic plants harboring a genomic fragment of the BORR gene fused to a beta-

250 glucuronidase (GUS) gene before the STOP codon. As expected, strong GUS activity

251 was observed in both the shoot and root meristems of seedlings, indicating that

$252 B O R R$ is expressed in proliferating cells (Fig. 5A-C). In addition, BORR was also

253 found to be strongly expressed in flowering tissues including both the male and

254 female reproductive organs (Fig. 5D-F).

255 To reveal the subcellular localization of the CPC components in plants, we

256 made use of the functional BORR reporter line used for the complementation

257 studies above. In addition, we constructed reporter lines in which the genomic

258 region of INCENP was fused to an ORF encoding for GFP. In contrast to BORR, only 
259 the N-terminal (GFP:INCENP) GFP fusion of INCENP could complement the lethal

260 phenotype of incenp homozygous mutants (Supplemental Fig. S1D and E). For

261 AUR3, we used a previously published reporter line (AUR3:GFP) in the wildtype

262 background (Komaki and Schnittger, 2017).

First, we crossed the three CPC reporter lines with RFP:TUA5 expressing

264 plants to check the localization of CPC components during mitosis. All three CPC

265 components showed the same localization pattern (Fig. 5G; Supplemental Movies

266 S1-3). In interphase, they localized to the nucleus. Before nuclear envelope

267 breakdown (NEB), the CPC components strongly accumulated at the kinetochores

268 until anaphase onset. Once chromosomes moved toward the spindle poles, they

269 localized to the middle part of the phragmoplast. Interestingly, in early telophase,

270 the CPC components moved back to the nucleus even though there still was an

271 expanding phragmoplast.

272 To corroborate that all three CPC components co-localize, we created

273 transgenic plants which expressed BORR:RFP and GFP:INCENP, BORR:RFP

274 together with AUR3:GFP and RFP:INCENP along with AUR3:GFP (Table 1).

275 Microscopical analyses revealed a tight co-localization pattern through the cell

276 cycle in all three lines, suggesting that BORR, INCENP and AUR3 work together as a 
277 plant CPC (Fig. 5H; Supplemental Fig. S3 and 4; Supplemental Movies S4-6).

278 In other organisms, it has been reported that the CPC localizes to the inner

279 centromere region to monitor kinetochore-microtubule attachments (Hindriksen

280 et al., 2017). To reveal the localization of the CPC precisely, we crossed the

281 BORR:GFP line with the inner kinetochore marker RFP:CENH3. Just after NEB, these

282 two fluorescent reporters showed a high level of overlapping signal. After

283 prometaphase, BORR:GFP localized closer to the inner region of the kinetochore

284 than RFP:CENH3. Yet, both proteins still overlapped in their localization pattern.

285 Shortly before anaphase onset, RFP:CENH3 formed two lines along the metaphase

286 plate, and BORR:GFP localized between these two lines with no overlap (Fig. 6;

287 Supplemental Movie S7). This result demonstrates that the CPC localizes to the

288 inner centromere region in plants.

289 In humans, Borealin function is regulated by phosphorylation. Especially the

290 phosphorylation of S219, a putative Cdk1 target residue, in the central region of the

291 protein affects its stability and centromere localization (Kaur et al., 2010; Date et

292 al., 2012). Since this Cdk1 phosphorylation site resides in the most conserved

293 region between human and plant Borealin is conserved in BORR (Figure 1B), we

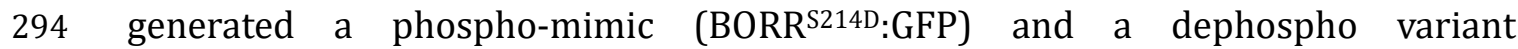




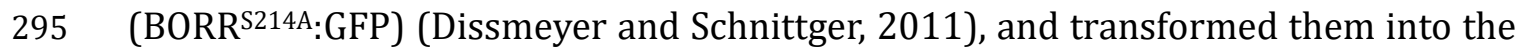

296 heterozygous borr-1 mutants to evaluate their functionality. Notably, both

297 constructs could complement the lethal phenotype of borr-1 mutant plants, and

298 showed a normal BORR localization pattern (Supplemental Fig. S1A-C). Thus, the

299 physiological importance of this conserved CDK target motif has yet to be resolved

300 in plants.

301

302 Expression pattern and subcellular localization of the CPC components in

303 meiosis

304 Since the plant meiotic spindle checkpoint seems to be less stringent (Wijnker and

305 Schnittger, 2013; Komaki and Schnittger, 2016), we asked whether BORR and

306 INCENP are present in meiosis. Analyzing male meiosis, we found that both

307 proteins localized to kinetochores until the onset of anaphase I (Fig. 7A and B;

308 Supplemental Movies S8 and S9). Interestingly, although no cytokinesis occurs

309 after meiosis I in Arabidopsis meiocytes, both proteins localized to the division

310 plane shortly after anaphase I either representing a late anaphase midzone or a

311 phragmoplast midzone-like structure (Fig. 7A and B; Supplemental Movies S8 and

312 S9). The transition between both phases is currently only poorly defined but the 
313 localization of BORR and INCENP could possibly contribute to the understanding of

314 the composition and dynamics of these structures.

315 The localization of BORR and INCENP in the second meiotic division

316 resembled the localization of both proteins in mitosis, i.e. at the kinetochores and

317 subsequently at the phragmoplast (Fig. 7A and B; Supplemental Movies S8 and S9). 


\section{Discussion}

321 The CPC is essential for proper cell division in animals and yeast. Whether CPC

322 activity exists in plants and how the potential complex is composed was up to the

323 presented work not clear. Here, we have identified and characterized BORR, a

324 Borealin homolog in Arabidopsis. While the presence of a functional homolog of

325 Survivin in plants is currently still unclear, the existence of BORR together with

326 localization data for AUR3 and an INCENP homolog demonstrates that a CPC is

327 present in plants and of equal importance as in animals.

328 BORR and INCENP localize to kinetochores in mitosis and meiosis. Both

329 proteins could also be co-precipitated from seedlings indicating that BORR and

330 INCENP indeed work in one complex. Consistent with previous reports, we

331 observed that AUR3 accumulates at mitotic kinetochores (Fig. 5G; Supplemental

332 Movie S3) (Demidov et al., 2005), while AUR1 and AUR2 localize to the mitotic

333 spindle (Van Damme et al., 2011). In addition, out of the three AUR proteins in

334 Arabidopsis, only AUR3 interacted with INCENP in our Y2H assays (Fig. 4). These

335 data suggest that only AUR3 acts as the catalytic subunit of the CPC at the inner

336 centromere in plants.

337

In animals, the CPC localizes to inner centromere to monitor inter- 
338 kinetochore tension. Since proper kinetochore-microtubule attachments are not

339 established during prophase, the distance between inner centromere and

340 kinetochores is very small allowing the CPC-dependent centromere-localized

341 Aurora B activity to act on kinetochores and by to destabilize erroneous

342 attachments of microtubules.

343 Once proper attachments are formed and inter-kinetochore tension is built

344 up, Aurora B localized to inner centromere is spatially separated from kinetochores

345 leading to the formation of a stable bipolar spindle. Since we found that the

346 kinetochore signals moved away from BORR signals during cell-cycle progression,

347 we propose that the plant CPC also acts as a tension sensor.

348 At anaphase onset, the animal CPC translocates from kinetochores to the

349 cell division plane. Although plant cell division is strikingly different (Müller and

350 Jürgens, 2016), we could show that Arabidopsis BORR, INCENP and AUR3 also

351 accumulate at the division plane at the beginning of cell division (Fig. 5G;

352 Supplemental Movie S1-3). Interestingly, they accumulate the reforming nuclei at

353 telophase before the expanding phragmoplast is completely disassembled, i.e.

354 cytokinesis is finished, while in animals the CPC stays at the cleavage site until the

355 two daughter cells are formed (Carmena et al., 2012). 
Remarkably, previous studies revealed that the two alpha-Aurora members,

357 AUR1 and AUR2, localize to the division plane until the end of cytokinesis

358 (Demidov et al., 2005; Kawabe et al., 2005). Therefore, the plant CPC might be

359 needed for the initiation but may not be necessary for later steps of cell division. In

360 animals, TPX2 recruits Aurora A to the division plane (Kufer et al., 2002). However,

361 TPX2 does not localize to the division plane in plants although it and its homologs

362 also interact with alpha-Aurora members in Arabidopsis (Petrovská et al., 2012;

363 Boruc et al., 2019). Thus, it is still not clar how alpha-Aurora localization to the

364 division plane is controlled.

366 in plants that has affinity to the plus-end of microtubules and causes the

367 localization of the CPC, i.e. AUR3 to kinetochores. After separation of the

368 chromosomes in anaphase, this or a different factor then promotes the

369 accumulation in the spindle midzone/early phragmoplast.

370 Since each component of the CPC is needed for its activity, loss of any CPC

371 component leads to the same mutant phenotypes as seen in Aurora B mutants

372 (Honda et al., 2003; Vader et al., 2006). CPC mutants typically exhibit cell division

373 defects and lagging chromosomes resulting from incorrect microtubule- 
374 kinetochore attachments. These phenotypes are frequently coupled with ploidy

375 changes causing cancer in mammals (Tang et al., 2017). Notably, a complete loss-

376 of-function of any of the CPC components leads to lethality (Cutts et al., 1999; Uren

377 et al., 2000; Lu et al., 2008; Yamanaka et al., 2008). The sporophyte of borr-1

378 heterozygous knockout plants grew like the wildtype. However, no homozygous

379 borr mutants could be recovered and the heterozygous mutants harbor

380 undeveloped ovules, aborted seeds, and embryonic defects in the forming siliques.

381 Similar effects were observed in the INCENP mutant wyr (Kirioukhova et al., 2011).

382 However, in contrast to borr, the loss of INCENP causes an arrest in development of

383 both the female and the male gametophytes. We can currently not rule out whether

384 INCENP has a specific and BORR-independent function during the gametophyte life

385 phase. It also possible that INCENP has a shorter half-life than BORR, given that it is

386 a large protein, and that hence the gametophytes run out of sporophytically

387 inherited protein levels much earlier than it is the case for the much smaller BORR

388 protein.

Using knock-down plants, we could further reveal that reduction of BORR

390 results in mitotic defects including lagging chromosomes and abnormal cell

391 division which appear to be likely caused by a compromised localization of AUR3. A 
392 previous study reported that hesperadin treatment, which inhibits the AUR3

393 kinase activity in vitro, induces lagging chromosomes in tobacco BY-2 cells

394 (Kurihara et al., 2006), suggesting that the AUR3 function in chromosome 395 segregation is conserved in the plant lineage.

396 Interestingly, the BORR knockdown plants showed a typical bonsai

397 phenotype, which is characterized by the inhibition of internode elongation and

398 the premature termination of the shoot apical meristem. Although the molecular

399 mechanism is still not known, the bonsai phenotype is associated with a reduction

400 of APC/C activity (Saze and Kakutani, 2007; Zheng et al., 2011).

401 The SAC is another M-phase checkpoint, which works together with the CPC

402 to ensure faithful chromosome segregation. The primary role of the SAC is delaying

403 APC/C activity until all kinetochores are properly attached to the spindle

404 microtubules. Therefore, one possible explanation of the bonsai phenotype is that

405 the SAC is over-activated in BORR knockdown plants. Indeed, these two M-phase

406 checkpoints are directly or indirectly connected in other organisms (Trivedi and

407 Stukenberg, 2016). Further studies are needed to understand the relationship

408 between SAC and CPC in plants.

409 The final non-catalytic CPC subunit, Survivin, remains elusive in plants. 
410 Survivin localizes to the inner centromere upon phosphorylation of histone H3 at

411 Thr3, which in animals is catalyzed by the Haspin kinase (Kelly et al., 2010).

412 Survivin localization is required for recruiting the entire CPC to the inner

413 centromere. Therefore, inhibition of Haspin kinase activity leads to the dissociation

414 of the CPC from inner centromere in mammals. Recently, it was shown that

415 inhibition of Haspin kinase activity with 5-iodotubercidin induces the disruption of

416 AUR3 localization at the inner centromere in BY-2 tobacco culture cells as well

417 (Kozgunova et al., 2016). Although this result indicates that Haspin kinase activity

418 is important for proper AUR3 localization at the inner centromere, no Survivin

419 homolog could be identified in plants on a sequence level. However, a functional

420 homolog might still exist. Alternatively, plants might employ a different mechanism

421 for CPC localization.

422 The phosphorylation status of its different components is of key importance

423 for the regulation of the CPC in animals and yeast. For instance, yeast INCENP is

424 cooperatively phosphorylated by Cdk1 and Aurora, which prevents the CPC binding

425 to the spindle before anaphase (Goto et al., 2006; Nakajima et al., 2011). In

426 addition, Casein kinase 2 phosphorylates the human Survivin, which leads to its

427 exclusion from the nucleus in interphase (Barrett et al., 2011). Borealin is also 
428 phosphorylated by many kinases, including $\mathrm{Cdk} 1$ that is required for the targeting

429 of the CPC to kinetochores (Kaur et al., 2010; Date et al., 2012). However, the

430 mutation of a conserved CDK phosphorylation site neither obviously altered BORR

431 localization nor reduced the activity of the protein in a way that it would result in a

432 mutant phenotype. Hence, further work is needed to shed light on the regulation of

433 the plant CPC with the present study opening the door for an in-depth analysis of

434 the CPC function in plants with focus on kingdom-specific aspects of its regulation

435 and activity.

436

MATERIALS AND METHODS

438

Plant Materials and Growth Conditions

The Arabidopsis thaliana accession Columbia (Col-0) was used as the wildtype in

440 this study. All mutants are in the Col-0 background. Plants were grown on a solid

441 medium containing half-strength Arabidopsis nutrient solution (Haughn and

442 Somerville, 1986), 1\%(w/v) sucrose and 1.5\% (w/v) agar in a growth chamber

443 (16h of light; $21^{\circ} \mathrm{C} / 8 \mathrm{~h}$ of dark; $18^{\circ} \mathrm{C}$ ). The T-DNA insertion line GABI_65B09 (wyr-

444 2) was obtained from the Nottingham Arabidopsis Stock Center. The borr-1 line

445 was generated by CRISPR/CAS9 (Fauser et al., 2014). Primer pairs for genotyping 
446 are described in Supplemental Table S1 and Supplemental Fig. S1.

448 Plasmid Construction and Transgenic Plants

449 The plasmid construction for the CRISPR/CAS9 system was performed as

450 described in Fauser et al. (2014). To obtain the borr knockout plants, 20-bp gene-

451 specific spacer sequences of BORR gene (Supplemental Table S1) were cloned into

452 the pEn-Chimera, followed by LR recombination reactions with the destination

453 vector pDe-CAS9. The plasmid construction for the artificial microRNA system was

454 performed as described in Carbonell et al. (Carbonell et al., 2014). To obtain the

455 BORR knockdown plants, 75-bp gene-specific sequences of BORR gene with

456 AtMIR390a backbone (Carbonell et al., 2014) (Supplemental Table S2) were

457 synthesized and cloned into $p D O N R 221$, followed by LR recombination reactions

458 with the destination vector $p G W B 602$. To create the PRO BORR:BORR:GUS construct, 2

$459 \mathrm{~kb}$ upstream of the start codon and $1 \mathrm{~kb}$ downstream of the stop codon of the BORR

460 gene were amplified by PCR and cloned into $p E N T R 2 B$ by SLiCE. The SmaI site was

461 inserted in front of the stop codon of the BORR construct. The resulting construct

462 was linearized by SmaI digestion and was ligated to the GUS gene, followed by LR

463 recombination reactions with the destination vector pGWB501 (Nakagawa et al., 


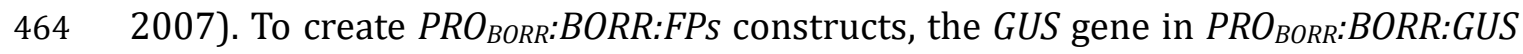

465 construct was replaced by the ORF for monomeric GFP (mGFP) or TagRFP-T. To

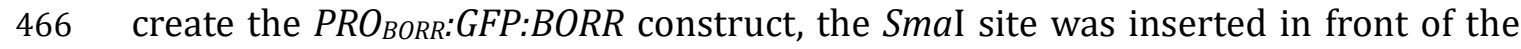

467 start codon of BORR construct. To create PROINCENP:FPS:INCENP, the genomic

468 fragment of INCENP gene was amplified by PCR and cloned into $p E N T R 2 B$ by SLiCE

469 method. The SmaI site was inserted in front of the start codon of INCENP. The

470 resulting construct was linearized by SmaI digestion and was ligated to the $m G F P$

471 or $m R U B Y 3$ gene, followed by LR recombination reactions with the destination

472 vector $p G W B 501$. Primer pairs for plasmid construction are described in

473 Supplemental Table S1. Transgenic plants were generated by the floral dip method.

474 The Agrobacterium tumefaciens strain GV3101 ( $p M P 90$ ) harboring the gene of

475 interest on a binary plasmid was grown in $3 \mathrm{ml}$ of LB media at $28^{\circ} \mathrm{C}$. Agrobacteria

476 were resuspended in $3 \mathrm{ml}$ of transformation buffer containing $5 \%$ sucrose and

$477 \quad 0.05 \%$ silwet L-77, and used for plant transformation.

478

479 Expression Analysis by qRT-PCR

480 Total RNA was isolated from 7 day-old seedlings with the RNeasy Plant Mini Kit

481 (Qiagen). $300 \mathrm{mg}$ of total RNA were reverse transcribed with ReverTra Ace qPCR 
482 RT Master Mix with gDNA Remover (TOYOBO) according to the manufacturer's

483 instructions. Real-time PCR was performed using the Roche LightCycler 480 and

484 the TB Green Premix Ex Taq (TaKaRa). PP2AA3 (AT1G13320) was used as the

485 reference gene (Czechowski et al., 2005). Primer pairs for BORR and PP2AA3 are

486 described in Supplemental Table S1. All experiments were performed in three

487 biological replicates.

489 Confocal Microscopy and Image Analysis

490 Root tips of 5 day-old seedlings were used for live cell imaging. Samples were put

491 on glass bottom dishes and covered with a solid medium containing half-strength

492 Arabidopsis nutrient solution, 1\% sucrose and 1.5\% agar. Confocal images of

493 mitotic cells were acquired by an inverted Nikon ECLIPSE Ti-U microscope

494 equipped with a YOKOGAWA CSU-X spinning disc detector unit connected to an

495 EM-CCD camera (iXon3 DU897; Andor) and a laser combiner system (500 series;

496 Andor), using a Plan Apo 60x/1.20 water immersion objective. GFP was excited at

$497488 \mathrm{~nm}$ with a 520/35 emission filter and TagRFP-T and mRUBY3 at $561 \mathrm{~nm}$ with a

$498617 / 73$ emission filter. Images were obtained at 20 second intervals and corrected

499 for sample drift using the StackReg plugin (Image J version 1.49). To obtain line 
500 profile data, images were analyzed by the RGB Profiler plugin (ImageJ version

501 1.49).

502 For meiotic live cell imaging, flower buds from 1 month-old plants were

503 used. Sample preparation was performed as described in Prusicki et al., (2019)

504 (Prusicki et al., 2018).

505 Images were obtained every 1 min for BORR:GFP and every 3 min for GFP:INCENP.

506 Images were corrected for the sample drift by the StackReg plugin (ImageJ version

507 1.49).

508

509 GUS Histochemical Analysis

510 Samples were fixed in $90 \%$ acetone for $15 \mathrm{~min}$ and were washed in $50 \mathrm{mM}$ sodium

511 phosphate buffer. The fixed samples were incubated in GUS solution $(50 \mathrm{mM}$

512 sodium phosphate buffer, $\mathrm{pH} 7.0,0.5 \%(\mathrm{v} / \mathrm{v})$ Triton $\mathrm{X}-100,0.5 \mathrm{mM} \mathrm{K} \mathrm{Fe}_{3}(\mathrm{CN})_{6}, 0.5$

$513 \mathrm{mM} \mathrm{K}_{4} \mathrm{Fe}(\mathrm{CN})_{6}$ and $0.5 \mathrm{mg} \mathrm{ml}^{-1} \mathrm{X}$-gluc) for $1 \mathrm{~h}$ at $37^{\circ} \mathrm{C}$. After staining, the samples

514 were cleared in chloral hydrate solution (8g chloral hydrate, $1 \mathrm{~mL}$ 100\% glycerol, 2

$515 \mathrm{~mL}$ distilled water). 
518 Y2H assays were performed as described in Komaki and Schnittger (2017). All of

519 the cDNAs tested were amplified by PCR using gene specific primers from cDNA

520 made from total RNA of wildtype Arabidopsis, followed by PCR with universal attB

521 primers, and cloned into pDONR221. The subcloned BORR cDNA was recombined

522 into $p G B T 9-C$ (DNA-BD), which GAL4-BD is fused with C-terminus of BORR by LR

523 recombination reactions. The other subcloned cDNAs were recombined into the

524 conventional vector $p G B T 9$ (DNA-BD) or $p G A D 424$ (AD). Primer pairs for plasmid

525 construction are described in Supplemental Table S1.

526

527 Protein Extraction and Co-Immunoprecipitation Assay

$5281 \mathrm{~g}$ of 7 day-old seedlings expressing BORR:RFP with GFP:INCENP or GFP was

529 ground to a fine powder in liquid nitrogen with mortar. Total protein was extracted

530 in $2 \mathrm{~mL}$ of extraction buffer containing $50 \mathrm{mM}$ Tris- $\mathrm{HCl}, \mathrm{pH} 8.0,150 \mathrm{mM} \mathrm{NaCl}, 1 \%$

531 IGEPAL CA-630, and a EDTA-Free Protease Inhibitor Cocktail (Roche) for 30 min on

532 ice, and centrifuged for $10 \mathrm{~min}$ at $20,000 \mathrm{~g}$ at $4^{\circ} \mathrm{C}$. The supernatant was incubated

533 for $1 \mathrm{~h}$ on ice with anti-GFP magnetic beads (Miltenyi Biotec), and beads were

534 washed 4 times with extraction buffer on the magnetic field. Then, the beads were

535 boiled in SDS sample buffer to release the proteins. Protein samples were detected 
536 with 1:2,000 diluted anti-GFP (A6455; Thermo Scientific) and 1:1,000 diluted anti-

537 RFP (AB233; evrogen) as primary antibodies and subsequently with 1:10,000

538 diluted anti-rabbit IgG, HRP-linked antibody (NA934; GE Healthcare) as secondary

539 antibody.

540

541 Accession Numbers

542 Sequence data from this article can be found in Arabidopsis Information Resource

543 (TAIR) - database under the following accession numbers: AUR1 (AT4G32830),

544 AUR2 (AT2G25880), AUR3 (AT2G45490), BORR (AT4G39630), INCENP/WYRD

545 (AT5G55820). Borealin protein sequence data of other organisms from this article

546 can be found in the NCBI data libraries under the following accession numbers:

547 Brachypodium distachyon (XP_003570304.1), Citrus clementina (XP_006428073.1),

548 Drosophila melanogaster (NP_609279.1), Homo sapiens (NP_001243804.1),

549 Marchantia polymorpha (PTQ34788.1), Micromonas commoda (XP_002503544.1),

550 Mus musculus (NP_080836.3), Oryza sativa (XP_015650359.1), Physcomitrella

551 patens (XP_024357151.1), Populus trichocarpa (XP_024458072.1), Saccharomyces

552 cerevisiae (AJV31725.1), Schizosaccharomyces pombe (CAA22184.2), Selaginella

553 moellendorffii (XP_024537708.1), Vitis vinifera (XP_002280684.1), Xenopus 
554 tropicalis (NP_001002902.1), Zea mays (NP_001142076.1).

555

556 SUPPLEMENTAL DATA

557 The following supplemental materials are available.

558 Supplemental Figure S1. Complementation test of BORR and INCENP mutants.

559 Supplemental Figure S2. Both BORR and AUR3 localize to inner centromeres.

560 Supplemental Table S1. Primers used in this study.

561 Supplemental Table S2. Synthesized oligonucleotides used in this study.

562 Supplemental Movie S1. Subcellular localization of GFP:INCENP during mitosis.

563 Supplemental Movie S2. Subcellular localization of BORR:GFP during mitosis.

564 Supplemental Movie S3. Subcellular localization of AUR3:GFP during mitosis.

565 Supplemental Movie S4. Co-localization of AUR3:GFP and BORR:RFP.

566 Supplemental Movie S5. Co-localization of AUR3:GFP and RFP:INCENP.

567 Supplemental Movie S6. Co-localization of GFP:INCENP and BORR:RFP.

568 Supplemental Movie S7. Comparison of subcellular localization between BORR:GFP

569 and RFP:CENH3.

570 Supplemental Movie S8. Subcellular localization of BORR:GFP during meiosis.

571 Supplemental Movie S9. Subcellular localization of GFP:INCENP during meiosis. 


\section{Acknowledgments}

574 We thank Konstantinos Lampou for critical reading and helpful comments to the

575 manuscript. We are grateful to the University of Hamburg for core funding.

576

\section{$577 \quad$ Footnotes}

578 This work was supported through a DFG grant (SCHN 736/8-1) to A.S., and a JSPS

579 KAKENHI Grant (JP18K45678) to S.K. In addition support of MEXT KAKENHI,

580 Grant-in-Aid for Scientific Research on Innovative Areas (JP19H04864) to S.K. and

581 core funding of the University of Hamburg to A.S. is greatly acknowledged. 


\section{Functional analysis of the chromosomal passenger complex in}

\section{Arabidopsis}

4 Shinichiro Komaki ${ }^{1,2}$, Hidenori Takeuchi3,4, Yuki Hamamura², Maren Heese ${ }^{2}$, Takashi

5 Hashimoto ${ }^{1}$, and Arp Schnittger ${ }^{2, *}$

6

7 Key words: Cell division, spindle assembly checkpoint, phragmoplast, Aurora B

$9{ }^{1}$ Nara Institute of Science and Technology, Graduate School of Biological Sciences,

10 8916-5 Takayama, Ikoma, Nara 630-0192, Japan

112 University of Hamburg, Institute for Plant Sciences and Microbiology, Department

12 of Developmental Biology, Ohnhorststr. 18, D-22609 Hamburg, Germany

$13{ }^{3}$ Institute of Transformative Bio-Molecules (WPI-ITbM), Nagoya University, Furo-

14 cho, Chikusa-ku, Nagoya, Aichi 464-8601, Japan.

154 Institute for Advanced Research, Nagoya University, Furo-cho, Chikusa-ku,

16 Nagoya, Aichi 464-8602, Japan

17 * For correspondence arp.schnittger@uni-hamburg.de, Phone: +49 4042816 502, 
A key regulator of cell division in all eukaryotes is the kinase Aurora B, which is central functions during cell division. On the one hand, it is essential for the correct, i.e. balanced, segregation of chromosomes in mitosis and meiosis by controlling kinetochore function. On the other hand, Aurora B acts at the division plane, where it is necessary to complete cytokinesis. To accomplish these two spatially distinct functions, Aurora B in animals is guided to its sites of action by Borealin, INCENP, and Survivin that build together with Aurora B the chromosome passenger complex (CPC). However, besides Aurora homologs, only a candidate gene with restricted homology to INCENP has so far been described in Arabidopsis raising the question whether there exists a full complement of the $\mathrm{CPC}$ in plants and how Aurora homologs are targeted subcellularly. Here, we have identified and functionally characterized a Borealin homolog, BOREALIN RELATED (BORR), in Arabidopsis. This, together with detailed localization studies including the putative

Arabidopsis INCENP homolog, supports the existence of a CPC in plants. 


\section{INTRODUCTION}

36 Equal chromosome segregation during cell division is crucial for survival, growth, and reproduction of every organism. Chromosome segregation is assured by the Mphase checkpoint, which involves two regulatory units, the spindle assembly checkpoint (SAC) and the chromosomal passenger complex (CPC) (Carmena et al., 2012). anaphase. The SAC inhibits the Anaphase Promoting Complex/Cyclosome (APC/C), an E3 ubiquitin ligase, which mediates the degradation of Securin, an inhibitor of Separase, until all kinetochores are properly attached to microtubules of opposing poles (London and Biggins, 2014; Komaki and Schnittger, 2016). been found to consist of four proteins: Aurora kinase B (Aurora B), Borealin, Inner centromere protein (INCENP), and Survivin. The CPC fulfills several functions during mitosis. In particular, it is involved in ensuring that all kinetochores are attached to microtubules emanating from opposing poles (Kitagawa and Lee, 
bioRxiv preprint doi: https://doi.org/10.1101/2020.03.19.998880; this version posted March 20, 2020. The copyright holder for this preprint

(which was not certified by peer review) is the author/funder, who has granted bioRxiv a license to display the preprint in perpetuity. It is made available under aCC-BY-NC 4.0 International license.

53

54

response to low inter-kinetochore tension. Active Aurora B phosphorylates kinetochore proteins leading to the destabilization of erroneous microtubule attachments. Once proper kinetochore-microtubule attachments are established from opposing poles, which gives high inter-kinetochore tension, Aurora B is spatially separated from kinetochores resulting in proper bistable spindle formation.

Aurora B belongs to the Aurora kinase family of serine/threonine kinases that are highly conserved in the eukaryotic kingdom (van der Waal et al., 2012; Weimer et al., 2016). While yeast possesses a single Aurora homolog, mammals have three Aurora kinases, Aurora A, Aurora B, and Aurora C, among which only Aurora C acts in meiosis (Goldenson and Crispino, 2015). Since these three kinases share a common consensus phosphorylation motif, it is thought that interacting proteins are important for their localization and substrate specificity.

Aurora A interacts with the spindle assembly factor TPX2, and localizes to spindle microtubules to regulate spindle assembly (Gruss and Vernos, 2004). In contrast, Aurora B and Aurora C, the catalytic subunit of the $\mathrm{CPC}$, is involved in the correction of erroneous kinetochore-microtubule attachments, activation of the SAC, and cytokinesis in mitosis and meiosis. These diverse functions are based on 
bioRxiv preprint doi: https://doi.org/10.1101/2020.03.19.998880; this version posted March 20, 2020. The copyright holder for this preprint

(which was not certified by peer review) is the author/funder, who has granted bioRxiv a license to display the preprint in perpetuity. It is made available under aCC-BY-NC 4.0 International license.

71 its dynamic localization pattern controlled by the three non-catalytic subunits of the CPC (van der Horst and Lens, 2014).

INCENP is the largest non-catalytic subunit of the CPC, which in animals and

yeast directly binds to all other components of the complex. Borealin and Survivin

interact with the conserved N-terminal region of INCENP while Aurora B binds to

the C-terminal domain of INCENP, called IN-box (Carmena et al., 2012). The IN-box

is required for interaction with and activation of Aurora B (Honda et al., 2003).

While the N-terminus of Borealin acts as the INCENP-binding region its C-

terminus contains a homo-dimerization domain that is involved in a stable CPC

localization at centromeres (Bekier et al., 2015). In addition, the phosphorylation

status of the central part affects the centromere localization and steady-state level

of Borealin itself (Kaur et al., 2010; Date et al., 2012).

Aurora kinases in plants are categorized into two groups, alpha-Aurora

and beta-Aurora, based on the localization pattern and sequences (Weimer et al.,

and Aurora B/C groups. For instance, AUR1 and AUR2 in Arabidopsis, both 
bioRxiv preprint doi: https://doi.org/10.1101/2020.03.19.998880; this version posted March 20, 2020. The copyright holder for this preprint

(which was not certified by peer review) is the author/funder, who has granted bioRxiv a license to display the preprint in perpetuity. It is made available under aCC-BY-NC 4.0 International license.

paralleling Aurora B/C at the cell cleavage site. AUR3, a member of the beta-Aurora group, localizes to kinetochores, similar to Aurora B (Komaki and Schnittger, 2017), but in contrary to Aurora B, it does not accumulate at the division plane (Demidov et al., 2005).

While aur1 and aur2 single mutants do not show any obvious growth alterations, the aur1 aur2 double null mutant is gametophytic lethal (Van Damme et al., 2011). A weak loss-of-function aur1 aur2 double mutant exhibits altered division plane orientation, reduced pollen viability, and enhanced vascular cell differentiation. These defects can be rescued by expressing either AUR1 or AUR2 but not AUR3, indicating that alpha-Auroras and beta-Auroras have distinct functions (Van Damme et al., 2011; Demidov et al., 2014; Lee et al., 2019).

Given the sparse information about the non-catalytic subunits of the plant CPC, it is not even clear whether there is a conserved CPC function in plants. The putative homolog of INCENP in Arabidopsis has a long N-terminal region of unknown function, which is conserved only in plants. Although Arabidopsis incenp mutants, also known as wyrd (wyr), show defects in gametophytic cell division (Kirioukhova et al., 2011), it is still unclear whether Arabidopsis INCENP acts as part of a putative plant CPC because of missing information about its localization 
and binding partners.

Arabidopsis Borealin homolog, which colocalizes with the INCENP homolog to the inner centromere and the central domain of the phragmoplast. We also observed that only AUR3 acts as the catalytic subunit of the plant CPC. These data underscore the mixed features of plant Aurora kinases.

Here, we present the identification and functional characterization of an

\section{RESULTS}

\section{Identification of a putative Borealin homolog in plants}

As a first step to determine whether plants have a functional CPC, we searched for Borealin and Survivin homologs in the Arabidopsis genome. Given that the putative INCENP homolog of Arabidopsis, WYR, shares only very weak similarities with its animal counterpart (Kirioukhova et al., 2011), we expected the same to be the case for Borealin and Survivin. Indeed, standard BLAST searches did not result in the identification of likely candidates. Therefore, we made use of the fact that Borealin is transcriptionally controlled by the tumor suppressor protein Retinoblastoma in animals (Cam et al., 2004; Date et al., 2007). Mining a dataset of the genome-wide binding sites of the Arabidopsis Retinoblastoma homolog RETINOBLASTOMA- 
bioRxiv preprint doi: https://doi.org/10.1101/2020.03.19.998880; this version posted March 20, 2020. The copyright holder for this preprint (which was not certified by peer review) is the author/funder, who has granted bioRxiv a license to display the preprint in perpetuity. It is made available under aCC-BY-NC 4.0 International license.

RELATED (RBR1), revealed several unknown genes likely involved in cell division control (Bouyer et al., 2018) (Sup Fig. 1). One of these genes, AT4G39630, showed a weak similarity to Borealin and will be referred to as BOREALIN-RELATED (BORR) (Supplemental Fig. S1A).

The C-terminal region of the corresponding protein shows $37 \%$ similarity with the central region of human Borealin, which includes highly conserved consensus sites for CDK phosphorylation (Fig. 1A). A second stretch of homology can be found in the $\mathrm{N}$-terminus, which is predicted to adopt an alpha-helical structure. In animals and yeast this N-terminal alpha-helix forms a three-helical bundle with INCENP and Survivin (Fig. 1A) (Jeyaprakash et al., 2007). Notably, the Arabidopsis BORR is considerably shorter than the human homolog (233 aa versus 280 aa), partly as the result of a truncated C-terminal domain. Using $B O R R$ as a template, we found putative Borealin genes in all branches of the plant kingdom, including angiosperms, gymnosperms, pteridophytes, bryophytes, and algae (Fig. 1B - phylogenetic tree).

\section{Phenotypic analysis of borr mutants}

Since no mutants for BORR were available in the public mutant collections of 
bioRxiv preprint doi: https://doi.org/10.1101/2020.03.19.998880; this version posted March 20, 2020. The copyright holder for this preprint (which was not certified by peer review) is the author/funder, who has granted bioRxiv a license to display the preprint in perpetuity. It is made available under aCC-BY-NC 4.0 International license.

143 Arabidopsis, we generated a mutant by CRISPR/Cas9. The resulting borr-1 allele

144 has a $\mathrm{T}$ insertion in the $2^{\text {nd }}$ exon, i.e. between nucleotides 280 and 281 downstream

145 of the start codon leading to a stop codon and a predicted truncated protein of 67

146 amino acids (Supplemental Fig. S1A). While the heterozygous borr-1 plants grow as

147 the wildtype, we could never obtain homozygous mutant plants. Consistently, we

148 observed aborted seeds and undeveloped ovules in siliques of borr-1 +/- (Fig.

$1492 \mathrm{~A}, \mathrm{~B})$.

150

To assess whether this lethal phenotype was indeed due to the frameshift

151 mutation in the BORR gene, we constructed reporter lines in which the genomic

152 region of BORR was fused to an ORF encoding for GFP. Expression of either an N-

153 terminal (GFP:BORR) or C-terminal (BORR:GFP) GFP fusion to BORR

154 complemented the lethal phenotype of borr-1 mutant plants corroborating that

155 loss of BORR affects plant reproduction.

To address the nature of the lack of homozygous borr-1 mutants, we

conducted reciprocal crosses of heterozygous mutants with the wildtype. When we

used borr-1 +/- as male parent, the transmission rate was determined to be $44 \%$.

Consistently, 96\% of borr1+/- pollen resembled wild-type pollen and based on

DAPI-staining, contained two sperm cells. 
bioRxiv preprint doi: https://doi.org/10.1101/2020.03.19.998880; this version posted March 20, 2020. The copyright holder for this preprint (which was not certified by peer review) is the author/funder, who has granted bioRxiv a license to display the preprint in perpetuity. It is made available under aCC-BY-NC 4.0 International license.

rate was reduced to $29 \%$, indicating that $B O R R$ is especially needed for the suggesting that the reduced transmission of borr-1 through the female gametophyte originated shortly before or after/during fertilization. In accordance with this, we found 12\% unfertilized ovules/early arrested seeds and 19\% late aborted seeds when we used borr $-1+/-$ as the female $(n=250)$ in contrast to $3 \%$ unfertilized ovules/early arrested seeds and $0.3 \%$ late aborted seeds in control crosses when we used the wildtype as the female and male parent $(n=299)$ (Fig. 2A,B). delayed and distorted embryos or embryo-like structures in approximately $10 \%$ of all ovules/seeds analyzed when borr-1+/- was used as the female parent in crosses with the wildtype as a male versus $4 \%$ in the control crosses supporting a female gametophytic effect of borr ( $n=313$ and $n=408$ for the control cross) (Fig. 2C,D).

177 One likely explanation for this is that the divisions leading to the development of the embryo sac cause aneuploidy in borr that preclude and/or severely interfere 
bioRxiv preprint doi: https://doi.org/10.1101/2020.03.19.998880; this version posted March 20, 2020. The copyright holder for this preprint (which was not certified by peer review) is the author/funder, who has granted bioRxiv a license to display the preprint in perpetuity. It is made available under aCC-BY-NC 4.0 International license.

with embryo development.

In addition, $B O R R$ is needed during embryo development since the number of seeds with embryonic defects almost doubled in self-fertilized borr-1 mutants (Fig. 2D). Thus, BORR is an essential gene needed for cell proliferation and development during early stages of the plant life cycle.

To address the BORR function after embryo development, we generated BORR knockdown plants by expressing two artificial microRNAs (amiRNA) targeted against the $2^{\text {nd }}\left(\operatorname{amiBORR\# 1)}\right.$ and $3^{\text {rd }}$ exon (amiBORR\#2) of BORR, respectively (Fig. 3A). Most transgenic plants expressing amiBORR\#1 (19 out of 25) and amiBORR\#2 (15 out of 20) showed a dwarf phenotype. For the following analyses, we selected two transgenic plants for each construct (amiBORR\#1-1, amiBORR\#1-2, amiBORR\#2-1 and amiBORR\#2-2). All four knockdown plants had a similar level of BORR transcript reduction (Fig. 3B) and had a dwarf phenotype with curled leaves during the vegetative stage (Supplemental Fig. S2A). At the flowering stage, all BORR knockdown plants were bushy and exhibited a typical bonsai phenotype (sometimes also called broom stick phenotype), which is commonly observed in mutants with low APC/C activity and is characterized by short inflorescences, which are often curled at the very end with only a few 
bioRxiv preprint doi: https://doi.org/10.1101/2020.03.19.998880; this version posted March 20, 2020. The copyright holder for this preprint (which was not certified by peer review) is the author/funder, who has granted bioRxiv a license to display the preprint in perpetuity. It is made available under aCC-BY-NC 4.0 International license.

197 developing siliques (Supplemental Fig. S2B and C) (Saze and Kakutani, 2007;

198 Zheng et al., 2011).

Primary root growth was also compromised in all BORR knockdown plants

(Fig. 3C and D). Microscopic analyses of amiBORR\#1-1 revealed that the root

meristem size was reduced (Fig. 3E-G). Moreover, an aberrant pattern of cell all seedlings (10 out of 25 ), altered division patterns were also present in the proper cell division (Fig. 3E). segregation as well, amiBORR\#1-1 was introgressed into a transgenic line expressing both a microtubule (RFP:TUA5) and a centromere (GFP:CENH3) marker

209 (Komaki and Schnittger, 2017). Indeed, we could frequently observe lagging 210 chromosomes in amiBORR\#1-1 plant cells (9 out of 50), a phenotype that hardly 211 occurred in the wildtype control plant cells (1 out of 50) (Fig. $3 \mathrm{H}$ and I). To examine whether the lagging chromosomes are related to a compromised AUR3

213 localization, we introduced a previously generated AUR3:GFP reporter into 
bioRxiv preprint doi: https://doi.org/10.1101/2020.03.19.998880; this version posted March 20, 2020. The copyright holder for this preprint

(which was not certified by peer review) is the author/funder, who has granted bioRxiv a license to display the preprint in perpetuity. It is made available under aCC-BY-NC 4.0 International license.

215

could be still detected at the kinetochores in amiBORR\#1-1 plants, the signal intensity was much weaker than in wild-type plants, suggesting that Arabidopsis BORR ensures chromosome segregation through AUR3 localization (Fig. 3J and K). Taken together, corresponding to Borealin function in animals, BORR is required for proper chromosome segregation and cell division in Arabidopsis.

\section{Interaction scheme of CPC components in Arabidopsis}

To reveal the molecular network of the Arabidopsis $\mathrm{CPC}$, we investigated the interaction of BORR with INCENP and the three Aurora kinases of Arabidopsis.

Although Borealin has a conserved coiled-coil domain, which is known as an INCENP binding site in other organisms (Jeyaprakash et al., 2007), an interaction between BORR and INCENP was not detected by a yeast two-hybrid interaction assay (Y2H assay) (Fig. 4A). We next performed an in vivo co-immunoprecipitation (IP) assay. To this end, anti-GFP immuno-precipitates from total protein extracts of plants expressing both BORR:RFP and GFP:INCENP or from plants expressing BORR:RFP and free GFP as a negative control were probed with an anti-RFP antibody. BORR:RFP was only detected in the extract of plants co-expressing GFPINCENP, indicating that Arabidopsis BORR could be part of a CPC in vivo (Fig. 4C). 
bioRxiv preprint doi: https://doi.org/10.1101/2020.03.19.998880; this version posted March 20, 2020. The copyright holder for this preprint (which was not certified by peer review) is the author/funder, who has granted bioRxiv a license to display the preprint in perpetuity. It is made available under aCC-BY-NC 4.0 International license.

234 found that INCENP interacts specifically with AUR3 through its C-terminal region

while no interaction was detected with AUR1 or AUR2 (Fig. 4A, B). The C-terminal

241 (Sessa et al., 2005), as well as in chicken culture cells (Xu et al., 2009). Consistent INCENPW1723G completely failed to interact with AUR3 (Fig. 4B).

Expression pattern and subcellular localization of the CPC components in

mitosis

To investigate the spatial and temporal expression pattern of $B O R R$, we generated transgenic plants harboring a genomic fragment of the BORR gene fused to a betaglucuronidase (GUS) gene before the STOP codon. As expected, strong GUS activity was observed in both the shoot and root meristems of seedlings, indicating that 
bioRxiv preprint doi: https://doi.org/10.1101/2020.03.19.998880; this version posted March 20, 2020. The copyright holder for this preprint (which was not certified by peer review) is the author/funder, who has granted bioRxiv a license to display the preprint in perpetuity. It is made available under aCC-BY-NC 4.0 International license.

251

\section{2}

$B O R R$ is expressed in proliferating cells (Fig. 5A-C). In addition, BORR was also found to be strongly expressed in flowering tissues including both the male and female reproductive organs (Fig. 5D-F).

To reveal the subcellular localization of the CPC components in plants, we made use of the functional BORR reporter line used for the complementation studies above. In addition, we constructed reporter lines in which the genomic region of INCENP was fused to an ORF encoding for GFP. In contrast to BORR, only the N-terminal (GFP:INCENP) GFP fusion of INCENP could complement the lethal phenotype of incenp homozygous mutants (Supplemental Fig. S1D and E). For AUR3, we used a previously published reporter line (AUR3:GFP) in the wildtype background (Komaki and Schnittger, 2017).

First, we crossed the three CPC reporter lines with RFP:TUA5 expressing plants to check the localization of CPC components during mitosis. All three CPC components showed the same localization pattern (Fig. 5G; Supplemental Movies S1-3). In interphase, they localized to the nucleus. Before nuclear envelope breakdown (NEB), the CPC components strongly accumulated at the kinetochores until anaphase onset. Once chromosomes moved toward the spindle poles, they localized to the middle part of the phragmoplast. Interestingly, in early telophase, 
bioRxiv preprint doi: https://doi.org/10.1101/2020.03.19.998880; this version posted March 20, 2020. The copyright holder for this preprint

(which was not certified by peer review) is the author/funder, who has granted bioRxiv a license to display the preprint in perpetuity. It is made available under aCC-BY-NC 4.0 International license.

the CPC components moved back to the nucleus even though there still was an expanding phragmoplast.

To corroborate that all three CPC components co-localize, we created transgenic plants which expressed BORR:RFP and GFP:INCENP, BORR:RFP together with AUR3:GFP and RFP:INCENP along with AUR3:GFP (Table 1). Microscopical analyses revealed a tight co-localization pattern through the cell cycle in all three lines, suggesting that BORR, INCENP and AUR3 work together as a plant CPC (Fig. 5H; Supplemental Fig. S3 and 4; Supplemental Movies S4-6).

In other organisms, it has been reported that the CPC localizes to the inner centromere region to monitor kinetochore-microtubule attachments (Hindriksen et al., 2017). To reveal the localization of the CPC precisely, we crossed the BORR:GFP line with the inner kinetochore marker RFP:CENH3. Just after NEB, these two fluorescent reporters showed a high level of overlapping signal. After prometaphase, BORR:GFP localized closer to the inner region of the kinetochore than RFP:CENH3. Yet, both proteins still overlapped in their localization pattern. Shortly before anaphase onset, RFP:CENH3 formed two lines along the metaphase plate, and BORR:GFP localized between these two lines with no overlap (Fig. 6; Supplemental Movie S7). This result demonstrates that the CPC localizes to the 
inner centromere region in plants.

In humans, Borealin function is regulated by phosphorylation. Especially the phosphorylation of S219, a putative Cdk1 target residue, in the central region of the protein affects its stability and centromere localization (Kaur et al., 2010; Date et al., 2012). Since this Cdk1 phosphorylation site resides in the most conserved region between human and plant Borealin is conserved in BORR (Figure 1B), we

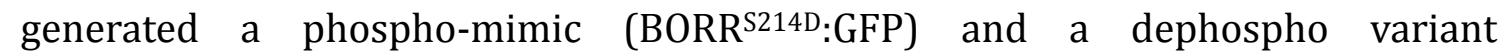
(BORR $214 \mathrm{~A}: \mathrm{GFP}$ ) (Dissmeyer and Schnittger, 2011), and transformed them into the heterozygous borr-1 mutants to evaluate their functionality. Notably, both constructs could complement the lethal phenotype of borr-1 mutant plants, and showed a normal BORR localization pattern (Supplemental Fig. S1A-C). Thus, the physiological importance of this conserved CDK target motif has yet to be resolved in plants.

\section{Expression pattern and subcellular localization of the CPC components in}

\section{meiosis}

Since the plant meiotic spindle checkpoint seems to be less stringent (Wijnker and Schnittger, 2013; Komaki and Schnittger, 2016), we asked whether BORR and 
bioRxiv preprint doi: https://doi.org/10.1101/2020.03.19.998880; this version posted March 20, 2020. The copyright holder for this preprint

(which was not certified by peer review) is the author/funder, who has granted bioRxiv a license to display the preprint in perpetuity. It is made available under aCC-BY-NC 4.0 International license.

305

306

307

308

309

310

311

312

INCENP are present in meiosis. Analyzing male meiosis, we found that both proteins localized to kinetochores until the onset of anaphase I (Fig. 7A and B;

Supplemental Movies S8 and S9). Interestingly, although no cytokinesis occurs after meiosis I in Arabidopsis meiocytes, both proteins localized to the division plane shortly after anaphase I either representing a late anaphase midzone or a phragmoplast midzone-like structure (Fig. 7A and B; Supplemental Movies S8 and S9). The transition between both phases is currently only poorly defined but the localization of BORR and INCENP could possibly contribute to the understanding of the composition and dynamics of these structures.

The localization of BORR and INCENP in the second meiotic division resembled the localization of both proteins in mitosis, i.e. at the kinetochores and subsequently at the phragmoplast (Fig. 7A and B; Supplemental Movies S8 and S9).

\section{Discussion}

The CPC is essential for proper cell division in animals and yeast. Whether CPC activity exists in plants and how the potential complex is composed was up to the presented work not clear. Here, we have identified and characterized $B O R R$, a Borealin homolog in Arabidopsis. While the presence of a functional homolog of 
bioRxiv preprint doi: https://doi.org/10.1101/2020.03.19.998880; this version posted March 20, 2020. The copyright holder for this preprint

(which was not certified by peer review) is the author/funder, who has granted bioRxiv a license to display the preprint in perpetuity. It is made available under aCC-BY-NC 4.0 International license.

Survivin in plants is currently still unclear, the existence of BORR together with localization data for AUR3 and an INCENP homolog demonstrates that a CPC is present in plants and of equal importance as in animals. BORR and INCENP localize to kinetochores in mitosis and meiosis. Both proteins could also be co-precipitated from seedlings indicating that BORR and INCENP indeed work in one complex. Consistent with previous reports, we observed that AUR3 accumulates at mitotic kinetochores (Fig. 5G; Supplemental Movie S3) (Demidov et al., 2005), while AUR1 and AUR2 localize to the mitotic spindle (Van Damme et al., 2011). In addition, out of the three AUR proteins in Arabidopsis, only AUR3 interacted with INCENP in our Y2H assays (Fig. 4). These data suggest that only AUR3 acts as the catalytic subunit of the CPC at the inner centromere in plants.

In animals, the CPC localizes to inner centromere to monitor interkinetochore tension. Since proper kinetochore-microtubule attachments are not established during prophase, the distance between inner centromere and kinetochores is very small allowing the CPC-dependent centromere-localized Aurora B activity to act on kinetochores and by to destabilize erroneous attachments of microtubules. 
bioRxiv preprint doi: https://doi.org/10.1101/2020.03.19.998880; this version posted March 20, 2020. The copyright holder for this preprint (which was not certified by peer review) is the author/funder, who has granted bioRxiv a license to display the preprint in perpetuity. It is made available under aCC-BY-NC 4.0 International license.

kinetochore signals moved away from BORR signals during cell-cycle progression,

we propose that the plant CPC also acts as a tension sensor.

cell division plane. Although plant cell division is strikingly different (Müller and accumulate at the division plane at the beginning of cell division (Fig. 5G; telophase before the expanding phragmoplast is completely disassembled, i.e. two daughter cells are formed (Carmena et al., 2012).

AUR1 and AUR2, localize to the division plane until the end of cytokinesis

(Demidov et al., 2005; Kawabe et al., 2005). Therefore, the plant CPC might be needed for the initiation but may not be necessary for later steps of cell division. In 
bioRxiv preprint doi: https://doi.org/10.1101/2020.03.19.998880; this version posted March 20, 2020. The copyright holder for this preprint

(which was not certified by peer review) is the author/funder, who has granted bioRxiv a license to display the preprint in perpetuity. It is made available under aCC-BY-NC 4.0 International license.

359

TPX2 does not localize to the division plane in plants although it and its homologs also interact with alpha-Aurora members in Arabidopsis (Petrovská et al., 2012; Boruc et al., 2019). Thus, it is still not clar how alpha-Aurora localization to the division plane is controlled.

It seems likely that there is a yet unidentified interaction partner of the CPC in plants that has affinity to the plus-end of microtubules and causes the localization of the CPC, i.e. AUR3 to kinetochores. After separation of the chromosomes in anaphase, this or a different factor then promotes the accumulation in the spindle midzone/early phragmoplast.

Since each component of the CPC is needed for its activity, loss of any CPC component leads to the same mutant phenotypes as seen in Aurora B mutants (Honda et al., 2003; Vader et al., 2006). CPC mutants typically exhibit cell division defects and lagging chromosomes resulting from incorrect microtubulekinetochore attachments. These phenotypes are frequently coupled with ploidy changes causing cancer in mammals (Tang et al., 2017). Notably, a complete lossof-function of any of the CPC components leads to lethality (Cutts et al., 1999; Uren et al., 2000; Lu et al., 2008; Yamanaka et al., 2008). The sporophyte of borr-1 heterozygous knockout plants grew like the wildtype. However, no homozygous 
bioRxiv preprint doi: https://doi.org/10.1101/2020.03.19.998880; this version posted March 20, 2020. The copyright holder for this preprint

(which was not certified by peer review) is the author/funder, who has granted bioRxiv a license to display the preprint in perpetuity. It is made available under aCC-BY-NC 4.0 International license.

377

borr mutants could be recovered and the heterozygous mutants harbor undeveloped ovules, aborted seeds, and embryonic defects in the forming siliques.

Similar effects were observed in the INCENP mutant wyr (Kirioukhova et al., 2011).

However, in contrast to borr, the loss of INCENP causes an arrest in development of both the female and the male gametophytes. We can currently not rule out whether INCENP has a specific and BORR-independent function during the gametophyte life phase. It also possible that INCENP has a shorter half-life than BORR, given that it is a large protein, and that hence the gametophytes run out of sporophytically inherited protein levels much earlier than it is the case for the much smaller BORR protein.

Using knock-down plants, we could further reveal that reduction of $B O R R$ results in mitotic defects including lagging chromosomes and abnormal cell division which appear to be likely caused by a compromised localization of AUR3. A previous study reported that hesperadin treatment, which inhibits the AUR3 kinase activity in vitro, induces lagging chromosomes in tobacco BY-2 cells (Kurihara et al., 2006), suggesting that the AUR3 function in chromosome segregation is conserved in the plant lineage.

Interestingly, the BORR knockdown plants showed a typical bonsai 
bioRxiv preprint doi: https://doi.org/10.1101/2020.03.19.998880; this version posted March 20, 2020. The copyright holder for this preprint (which was not certified by peer review) is the author/funder, who has granted bioRxiv a license to display the preprint in perpetuity. It is made available under aCC-BY-NC 4.0 International license.

395

phenotype, which is characterized by the inhibition of internode elongation and the premature termination of the shoot apical meristem. Although the molecular mechanism is still not known, the bonsai phenotype is associated with a reduction of APC/C activity (Saze and Kakutani, 2007; Zheng et al., 2011).

The SAC is another M-phase checkpoint, which works together with the CPC to ensure faithful chromosome segregation. The primary role of the SAC is delaying APC/C activity until all kinetochores are properly attached to the spindle microtubules. Therefore, one possible explanation of the bonsai phenotype is that the SAC is over-activated in BORR knockdown plants. Indeed, these two M-phase checkpoints are directly or indirectly connected in other organisms (Trivedi and Stukenberg, 2016). Further studies are needed to understand the relationship between SAC and CPC in plants.

The final non-catalytic CPC subunit, Survivin, remains elusive in plants. Survivin localizes to the inner centromere upon phosphorylation of histone H3 at Thr3, which in animals is catalyzed by the Haspin kinase (Kelly et al., 2010). Survivin localization is required for recruiting the entire CPC to the inner centromere. Therefore, inhibition of Haspin kinase activity leads to the dissociation of the CPC from inner centromere in mammals. Recently, it was shown that 
bioRxiv preprint doi: https://doi.org/10.1101/2020.03.19.998880; this version posted March 20, 2020. The copyright holder for this preprint (which was not certified by peer review) is the author/funder, who has granted bioRxiv a license to display the preprint in perpetuity. It is made available under aCC-BY-NC 4.0 International license.

413

414

415

416

417

inhibition of Haspin kinase activity with 5-iodotubercidin induces the disruption of AUR3 localization at the inner centromere in BY-2 tobacco culture cells as well (Kozgunova et al., 2016). Although this result indicates that Haspin kinase activity is important for proper AUR3 localization at the inner centromere, no Survivin homolog could be identified in plants on a sequence level. However, a functional homolog might still exist. Alternatively, plants might employ a different mechanism for CPC localization.

The phosphorylation status of its different components is of key importance for the regulation of the CPC in animals and yeast. For instance, yeast INCENP is cooperatively phosphorylated by Cdk1 and Aurora, which prevents the CPC binding to the spindle before anaphase (Goto et al., 2006; Nakajima et al., 2011). In addition, Casein kinase 2 phosphorylates the human Survivin, which leads to its exclusion from the nucleus in interphase (Barrett et al., 2011). Borealin is also phosphorylated by many kinases, including Cdk1 that is required for the targeting of the CPC to kinetochores (Kaur et al., 2010; Date et al., 2012). However, the mutation of a conserved CDK phosphorylation site neither obviously altered BORR localization nor reduced the activity of the protein in a way that it would result in a mutant phenotype. Hence, further work is needed to shed light on the regulation of 
the plant CPC with the present study opening the door for an in-depth analysis of the CPC function in plants with focus on kingdom-specific aspects of its regulation and activity.

\section{MATERIALS AND METHODS}

\section{Plant Materials and Growth Conditions}

437 The Arabidopsis thaliana accession Columbia (Col-0) was used as the wildtype in

438 this study. All mutants are in the Col-0 background. Plants were grown on a solid 439 medium containing half-strength Arabidopsis nutrient solution (Haughn and 440 Somerville, 1986), 1\% (w/v) sucrose and 1.5\% (w/v) agar in a growth chamber 441 (16h of light; $21^{\circ} \mathrm{C} / 8 \mathrm{~h}$ of dark; $18^{\circ} \mathrm{C}$ ). The T-DNA insertion line GABI_65B09 (wyr442 2) was obtained from the Nottingham Arabidopsis Stock Center. The borr-1 line 443 was generated by CRISPR/CAS9 (Fauser et al., 2014). Primer pairs for genotyping 444 are described in Supplemental Table S1 and Supplemental Fig. S1.

\section{Plasmid Construction and Transgenic Plants}

447 The plasmid construction for the CRISPR/CAS9 system was performed as described in Fauser et al. (2014). To obtain the borr knockout plants, 20-bp gene- 
bioRxiv preprint doi: https://doi.org/10.1101/2020.03.19.998880; this version posted March 20, 2020. The copyright holder for this preprint (which was not certified by peer review) is the author/funder, who has granted bioRxiv a license to display the preprint in perpetuity. It is made available under aCC-BY-NC 4.0 International license.

specific spacer sequences of BORR gene (Supplemental Table S1) were cloned into the pEn-Chimera, followed by LR recombination reactions with the destination vector pDe-CAS9. The plasmid construction for the artificial microRNA system was performed as described in Carbonell et al. (Carbonell et al., 2014). To obtain the BORR knockdown plants, 75-bp gene-specific sequences of BORR gene with AtMIR390a backbone (Carbonell et al., 2014) (Supplemental Table S2) were synthesized and cloned into $P D O N R 221$, followed by LR recombination reactions with the destination vector $p G W B 602$. To create the $P R O_{B O R R}: B O R R: G U S$ construct, 2 $\mathrm{kb}$ upstream of the start codon and $1 \mathrm{~kb}$ downstream of the stop codon of the BORR gene were amplified by PCR and cloned into $p E N T R 2 B$ by SLiCE. The SmaI site was inserted in front of the stop codon of the BORR construct. The resulting construct was linearized by SmaI digestion and was ligated to the GUS gene, followed by LR recombination reactions with the destination vector pGWB501 (Nakagawa et al., 2007). To create $P R O_{B O R R}: B O R R: F P S$ constructs, the GUS gene in $P R O_{B O R R: B O R R: G U S}$ construct was replaced by the ORF for monomeric GFP (mGFP) or TagRFP-T. To create the $P R O_{B O R R}: G F P: B O R R$ construct, the SmaI site was inserted in front of the start codon of BORR construct. To create PROINCENP:FPS:INCENP, the genomic fragment of INCENP gene was amplified by PCR and cloned into $p E N T R 2 B$ by SLiCE 
bioRxiv preprint doi: https://doi.org/10.1101/2020.03.19.998880; this version posted March 20, 2020. The copyright holder for this preprint

(which was not certified by peer review) is the author/funder, who has granted bioRxiv a license to display the preprint in perpetuity. It is made available under aCC-BY-NC 4.0 International license.

467

method. The SmaI site was inserted in front of the start codon of INCENP. The

resulting construct was linearized by SmaI digestion and was ligated to the $m G F P$ or $m R U B Y 3$ gene, followed by LR recombination reactions with the destination vector pGWB501. Primer pairs for plasmid construction are described in Supplemental Table S1. Transgenic plants were generated by the floral dip method. The Agrobacterium tumefaciens strain GV3101 (pMP90) harboring the gene of interest on a binary plasmid was grown in $3 \mathrm{ml}$ of $\mathrm{LB}$ media at $28^{\circ} \mathrm{C}$. Agrobacteria were resuspended in $3 \mathrm{ml}$ of transformation buffer containing 5\% sucrose and 0.05\% silwet L-77, and used for plant transformation.

\section{Expression Analysis by qRT-PCR}

Total RNA was isolated from 7 day-old seedlings with the RNeasy Plant Mini Kit (Qiagen). $300 \mathrm{mg}$ of total RNA were reverse transcribed with ReverTra Ace qPCR RT Master Mix with gDNA Remover (TOYOBO) according to the manufacturer's instructions. Real-time PCR was performed using the Roche LightCycler 480 and the TB Green Premix Ex Taq (TaKaRa). PP2AA3 (AT1G13320) was used as the reference gene (Czechowski et al., 2005). Primer pairs for BORR and PP2AA3 are described in Supplemental Table S1. All experiments were performed in three 
biological replicates.

\section{Confocal Microscopy and Image Analysis}

Root tips of 5 day-old seedlings were used for live cell imaging. Samples were put

on glass bottom dishes and covered with a solid medium containing half-strength

Arabidopsis nutrient solution, $1 \%$ sucrose and $1.5 \%$ agar. Confocal images of mitotic cells were acquired by an inverted Nikon ECLIPSE Ti-U microscope

EM-CCD camera (iXon3 DU897; Andor) and a laser combiner system (500 series;

Andor), using a Plan Apo 60x/1.20 water immersion objective. GFP was excited at

497 for sample drift using the StackReg plugin (ImageJ version 1.49). To obtain line profile data, images were analyzed by the RGB Profiler plugin (ImageJ version 
504 Images were corrected for the sample drift by the StackReg plugin (ImageJ version

\section{GUS Histochemical Analysis}

508 Samples were fixed in $90 \%$ acetone for $15 \mathrm{~min}$ and were washed in $50 \mathrm{mM}$ sodium

509 phosphate buffer. The fixed samples were incubated in GUS solution (50 mM

510 sodium phosphate buffer, $\mathrm{pH} 7.0,0.5 \%(\mathrm{v} / \mathrm{v})$ Triton $\mathrm{X}-100,0.5 \mathrm{mM} \mathrm{K} \mathrm{F}_{3} \mathrm{Fe}(\mathrm{CN})_{6}, 0.5$

$511 \mathrm{mM} \mathrm{K}_{4} \mathrm{Fe}(\mathrm{CN})_{6}$ and $0.5 \mathrm{mg} \mathrm{ml}^{-1} \mathrm{X}$-gluc) for $1 \mathrm{~h}$ at $37^{\circ} \mathrm{C}$. After staining, the samples

512 were cleared in chloral hydrate solution (8g chloral hydrate, $1 \mathrm{~mL} \mathrm{100 \%} \mathrm{glycerol,} 2$

513 mL distilled water).

\section{Yeast Two-Hybrid Assay (Y2H)}

516 Y2H assays were performed as described in Komaki and Schnittger (2017). All of

517 the cDNAs tested were amplified by PCR using gene specific primers from cDNA

518 made from total RNA of wildtype Arabidopsis, followed by PCR with universal attB

519 primers, and cloned into pDONR221. The subcloned BORR cDNA was recombined into $p G B T 9-C$ (DNA-BD), which GAL4-BD is fused with C-terminus of BORR by LR 
bioRxiv preprint doi: https://doi.org/10.1101/2020.03.19.998880; this version posted March 20, 2020. The copyright holder for this preprint

(which was not certified by peer review) is the author/funder, who has granted bioRxiv a license to display the preprint in perpetuity. It is made available under aCC-BY-NC 4.0 International license.

521

522 antibody.

recombination reactions. The other subcloned cDNAs were recombined into the conventional vector pGBT9 (DNA-BD) or pGAD424 (AD). Primer pairs for plasmid construction are described in Supplemental Table S1.

\section{Protein Extraction and Co-Immunoprecipitation Assay}

$1 \mathrm{~g}$ of 7 day-old seedlings expressing BORR:RFP with GFP:INCENP or GFP was ground to a fine powder in liquid nitrogen with mortar. Total protein was extracted in $2 \mathrm{~mL}$ of extraction buffer containing $50 \mathrm{mM}$ Tris-HCl, pH8.0, $150 \mathrm{mM} \mathrm{NaCl}, 1 \%$ IGEPAL CA-630, and a EDTA-Free Protease Inhibitor Cocktail (Roche) for 30 min on ice, and centrifuged for $10 \mathrm{~min}$ at $20,000 \mathrm{~g}$ at $4^{\circ} \mathrm{C}$. The supernatant was incubated for $1 \mathrm{~h}$ on ice with anti-GFP magnetic beads (Miltenyi Biotec), and beads were washed 4 times with extraction buffer on the magnetic field. Then, the beads were boiled in SDS sample buffer to release the proteins. Protein samples were detected with 1:2,000 diluted anti-GFP (A6455; Thermo Scientific) and 1:1,000 diluted antiRFP (AB233; evrogen) as primary antibodies and subsequently with 1:10,000 diluted anti-rabbit IgG, HRP-linked antibody (NA934; GE Healthcare) as secondary 
bioRxiv preprint doi: https://doi.org/10.1101/2020.03.19.998880; this version posted March 20, 2020. The copyright holder for this preprint (which was not certified by peer review) is the author/funder, who has granted bioRxiv a license to display the preprint in perpetuity. It is made available under aCC-BY-NC 4.0 International license.

\section{Accession Numbers}

540 Sequence data from this article can be found in Arabidopsis Information Resource

541 (TAIR) - database under the following accession numbers: AUR1 (AT4G32830), 542 AUR2 (AT2G25880), AUR3 (AT2G45490), BORR (AT4G39630), INCENP/WYRD

543 (AT5G55820). Borealin protein sequence data of other organisms from this article

544 can be found in the NCBI data libraries under the following accession numbers:

545 Brachypodium distachyon (XP_003570304.1), Citrus clementina (XP_006428073.1),

546 Drosophila melanogaster (NP_609279.1), Homo sapiens (NP_001243804.1),

547 Marchantia polymorpha (PTQ34788.1), Micromonas commoda (XP_002503544.1),

548 Mus musculus (NP_080836.3), Oryza sativa (XP_015650359.1), Physcomitrella

549 patens (XP_024357151.1), Populus trichocarpa (XP_024458072.1), Saccharomyces

550 cerevisiae (AJV31725.1), Schizosaccharomyces pombe (CAA22184.2), Selaginella

551 moellendorffii (XP_024537708.1), Vitis vinifera (XP_002280684.1), Xenopus

tropicalis (NP_001002902.1), Zea mays (NP_001142076.1).

SUPPLEMENTAL DATA

555 The following supplemental materials are available.

556 Supplemental Figure S1. Complementation test of BORR and INCENP mutants. 
557 Supplemental Figure S2. Both BORR and AUR3 localize to inner centromeres.

558 Supplemental Table S1. Primers used in this study.

559 Supplemental Table S2. Synthesized oligonucleotides used in this study.

560 Supplemental Movie S1. Subcellular localization of GFP:INCENP during mitosis.

561 Supplemental Movie S2. Subcellular localization of BORR:GFP during mitosis.

562 Supplemental Movie S3. Subcellular localization of AUR3:GFP during mitosis.

563 Supplemental Movie S4. Co-localization of AUR3:GFP and BORR:RFP.

564 Supplemental Movie S5. Co-localization of AUR3:GFP and RFP:INCENP.

565 Supplemental Movie S6. Co-localization of GFP:INCENP and BORR:RFP.

566 Supplemental Movie S7. Comparison of subcellular localization between BORR:GFP

567 and RFP:CENH3.

568 Supplemental Movie S8. Subcellular localization of BORR:GFP during meiosis.

569 Supplemental Movie S9. Subcellular localization of GFP:INCENP during meiosis.

\section{Acknowledgments}

572 We thank Konstantinos Lampou for critical reading and helpful comments to the manuscript. We are grateful to the University of Hamburg for core funding. 
bioRxiv preprint doi: https://doi.org/10.1101/2020.03.19.998880; this version posted March 20, 2020. The copyright holder for this preprint (which was not certified by peer review) is the author/funder, who has granted bioRxiv a license to display the preprint in perpetuity. It is made available under aCC-BY-NC 4.0 International license.

575

576

577

578

579

580

581

582

583

584

585

586

587

588

589

590

591

592

593

594

595

596

597

598

599

600

601

602

603

\section{Footnotes}

This work was supported through a DFG grant (SCHN 736/8-1) to A.S., and a JSPS

KAKENHI Grant (JP18K45678) to S.K. In addition support of MEXT KAKENHI,

Grant-in-Aid for Scientific Research on Innovative Areas (JP19H04864) to S.K. and

core funding of the University of Hamburg to A.S. is greatly acknowledged.

\section{References}

Adams RR, Wheatley SP, Gouldsworthy AM, Kandels-Lewis SE, Carmena M, Smythe C, Gerloff DL, Earnshaw WC (2000) INCENP binds the Aurora-related kinase AIRK2 and is required to target it to chromosomes, the central spindle and cleavage furrow. Curr Biol 10: 1075-1078

Barrett RM, Colnaghi R, Wheatley SP (2011) Threonine 48 in the BIR domain of survivin is critical to its mitotic and anti-apoptotic activities and can be phosphorylated by CK2 in vitro. Cell Cycle 10: 538-548

Bekier ME, Mazur T, Rashid MS, Taylor WR (2015) Borealin dimerization mediates optimal CPC checkpoint function by enhancing localization to centromeres and kinetochores. Nat Commun 6: 6775

Boruc J, Deng X, Mylle E, Besbrugge N, Van Durme M, Demidov D, Tomaštíková ED, Tan TC, Vandorpe M, Eeckhout D, Beeckman T, Nowack MK, De Jaeger G, Lin H, Liu B, Van Damme D (2019) TPX2-LIKE PROTEIN3 Is the Primary Activator of $\alpha$-Aurora Kinases and Is Essential for Embryogenesis. Plant Physiol 180: 1389-1405

Bouyer D, Heese M, Chen P, Harashima H, Roudier F, Grüttner C, Schnittger A (2018) Genome-wide identification of RETINOBLASTOMA RELATED 1 binding sites in Arabidopsis reveals novel DNA damage regulators. PLoS Genet 14: e1007797

Cam H, Balciunaite E, Blais A, Spektor A, Scarpulla RC, Young R, Kluger Y, Dynlacht BD (2004) A common set of gene regulatory networks links metabolism and growth inhibition. Mol Cell 16: 399-411 
bioRxiv preprint doi: https://doi.org/10.1101/2020.03.19.998880; this version posted March 20, 2020. The copyright holder for this preprint

(which was not certified by peer review) is the author/funder, who has granted bioRxiv a license to display the preprint in perpetuity. It is made available under aCC-BY-NC 4.0 International license.

Carbonell A, Takeda A, Fahlgren N, Johnson SC, Cuperus JT, Carrington JC (2014) New generation of artificial MicroRNA and synthetic trans-acting small interfering RNA vectors for efficient gene silencing in Arabidopsis. Plant Physiol 165: $15-29$

Carmena M, Wheelock M, Funabiki H, Earnshaw WC (2012) The chromosomal passenger complex (CPC): from easy rider to the godfather of mitosis. Nat Rev Mol Cell Biol 13: 789-803

\section{Cutts SM, Fowler KJ, Kile BT, Hii LL, O'Dowd RA, Hudson DF, Saffery R,} Kalitsis P, Earle E, Choo KH (1999) Defective chromosome segregation, microtubule bundling and nuclear bridging in inner centromere protein gene (Incenp)-disrupted mice. Hum Mol Genet 8: 1145-1155

Czechowski T, Stitt M, Altmann T, Udvardi MK, Scheible WR (2005) Genomewide identification and testing of superior reference genes for transcript normalization in Arabidopsis. Plant Physiol 139: 5-17

Date D, Dreier MR, Borton MT, Bekier ME, Taylor WR (2012) Effects of phosphatase and proteasome inhibitors on Borealin phosphorylation and degradation. J Biochem 151: 361-369

Date DA, Jacob CJ, Bekier ME, Stiff AC, Jackson MW, Taylor WR (2007) Borealin is repressed in response to p53/Rb signaling. Cell Biol Int 31: 1470-1481

Demidov D, Lermontova I, Weiss O, Fuchs J, Rutten T, Kumke K, Sharbel TF, Van Damme D, De Storme N, Geelen D, Houben A (2014) Altered expression of Aurora kinases in Arabidopsis results in aneu- and polyploidization. Plant J 80: $449-461$

Demidov D, Van Damme D, Geelen D, Blattner FR, Houben A (2005) Identification and dynamics of two classes of aurora-like kinases in Arabidopsis and other plants. Plant Cell 17: 836-848

Dissmeyer N, Schnittger A (2011) Use of phospho-site substitutions to analyze the biological relevance of phosphorylation events in regulatory networks. Methods Mol Biol 779: 93-138

Fauser F, Schiml S, Puchta H (2014) Both CRISPR/Cas-based nucleases and nickases can be used efficiently for genome engineering in Arabidopsis thaliana. Plant J 79: 348-359

Goldenson B, Crispino JD (2015) The aurora kinases in cell cycle and leukemia. Oncogene 34: 537-545

\section{Goto H, Kiyono T, Tomono Y, Kawajiri A, Urano T, Furukawa K, Nigg EA,} Inagaki M (2006) Complex formation of Plk1 and INCENP required for 
bioRxiv preprint doi: https://doi.org/10.1101/2020.03.19.998880; this version posted March 20, 2020. The copyright holder for this preprint (which was not certified by peer review) is the author/funder, who has granted bioRxiv a license to display the preprint in perpetuity. It is made available under aCC-BY-NC 4.0 International license.

metaphase-anaphase transition. Nat Cell Biol 8: 180-187

Gruss OJ, Vernos I (2004) The mechanism of spindle assembly: functions of Ran and its target TPX2. J Cell Biol 166: 949-955

Haughn GW, Somerville C (1986) Sulfonylurea-resistant mutants of Arabidopsis thaliana. Molecular and General Genetics MGG 204: 430-434

Hindriksen S, Lens SMA, Hadders MA (2017) The Ins and Outs of Aurora B Inner Centromere Localization. Front Cell Dev Biol 5: 112

Honda R, Körner R, Nigg EA (2003) Exploring the functional interactions between Aurora B, INCENP, and survivin in mitosis. Mol Biol Cell 14: 3325-3341

Jeyaprakash AA, Klein UR, Lindner D, Ebert J, Nigg EA, Conti E (2007) Structure of a Survivin-Borealin-INCENP core complex reveals how chromosomal passengers travel together. Cell 131: 271-285

Kaur H, Bekier ME, Taylor WR (2010) Regulation of Borealin by phosphorylation at serine 219. J Cell Biochem 111: 1291-1298

Kawabe A, Matsunaga S, Nakagawa K, Kurihara D, Yoneda A, Hasezawa S, Uchiyama S, Fukui K (2005) Characterization of plant Aurora kinases during mitosis. Plant Mol Biol 58: 1-13

Kelly AE, Ghenoiu C, Xue JZ, Zierhut C, Kimura H, Funabiki H (2010) Survivin reads phosphorylated histone $\mathrm{H} 3$ threonine 3 to activate the mitotic kinase Aurora B. Science 330: 235-239

Kirioukhova O, Johnston AJ, Kleen D, Kägi C, Baskar R, Moore JM, Bäumlein H, Gross-Hardt R, Grossniklaus U (2011) Female gametophytic cell specification and seed development require the function of the putative Arabidopsis INCENP ortholog WYRD. Development 138: 3409-3420

Kitagawa M, Lee SH (2015) The chromosomal passenger complex (CPC) as a key orchestrator of orderly mitotic exit and cytokinesis. Front Cell Dev Biol 3: 14

Komaki S, Schnittger A (2016) The spindle checkpoint in plants-a green variation over a conserved theme. Curr Opin Plant Biol 34: 84-91

Komaki S, Schnittger A (2017) The Spindle Assembly Checkpoint in Arabidopsis Is Rapidly Shut Off during Severe Stress. Dev Cell 43: 172-185.e5

Kozgunova E, Suzuki T, Ito M, Higashiyama T, Kurihara D (2016) Haspin has Multiple Functions in the Plant Cell Division Regulatory Network. Plant Cell Physiol 57: 848-861

Kufer TA, Silljé HH, Körner R, Gruss OJ, Meraldi P, Nigg EA (2002) Human TPX2 is required for targeting Aurora-A kinase to the spindle. J Cell Biol 158: $617-623$ 
bioRxiv preprint doi: https://doi.org/10.1101/2020.03.19.998880; this version posted March 20, 2020. The copyright holder for this preprint (which was not certified by peer review) is the author/funder, who has granted bioRxiv a license to display the preprint in perpetuity. It is made available under aCC-BY-NC 4.0 International license.

Kurihara D, Matsunaga S, Kawabe A, Fujimoto S, Noda M, Uchiyama S, Fukui K (2006) Aurora kinase is required for chromosome segregation in tobacco BY-2 cells. Plant J 48: 572-580

Lee KH, Avci U, Qi L, Wang H (2019) The $\alpha$-Aurora Kinases Function in Vascular Development in Arabidopsis. Plant Cell Physiol 60: 188-201

London N, Biggins S (2014) Signalling dynamics in the spindle checkpoint response. Nat Rev Mol Cell Biol 15: 736-747

\section{Lu LY, Wood JL, Ye L, Minter-Dykhouse K, Saunders TL, Yu X, Chen J (2008)} Aurora A is essential for early embryonic development and tumor suppression. $\mathrm{J}$ Biol Chem 283: 31785-31790

Müller S, Jürgens G (2016) Plant cytokinesis-No ring, no constriction but centrifugal construction of the partitioning membrane. Semin Cell Dev Biol 53: 10-18

Nakagawa T, Suzuki T, Murata S, Nakamura S, Hino T, Maeo K, Tabata R, Kawai T, Tanaka K, Niwa Y, Watanabe Y, Nakamura K, Kimura T, Ishiguro S (2007) Improved Gateway binary vectors: high-performance vectors for creation of fusion constructs in transgenic analysis of plants. Biosci Biotechnol Biochem 71: $2095-2100$

Nakajima Y, Cormier A, Tyers RG, Pigula A, Peng Y, Drubin DG, Barnes G (2011) Ipl1/Aurora-dependent phosphorylation of Sli15/INCENP regulates CPCspindle interaction to ensure proper microtubule dynamics. J Cell Biol 194: 137153

\section{Petrovská B, Cenklová V, Pochylová Z, Kourová H, Doskočilová A, Plíhal O,} Binarová L, Binarová P (2012) Plant Aurora kinases play a role in maintenance of primary meristems and control of endoreduplication. New Phytol 193: 590-604

Prusicki MA, Keizer EM, van Rosmalen RP, Komaki S, Seifert F, Müller K, Wijnker E, Fleck C, Schnittger A (2018) Live cell imaging of meiosis in Arabidopsis thaliana-a landmark system. bioRxiv 446922

Saze H, Kakutani T (2007) Heritable epigenetic mutation of a transposon-flanked Arabidopsis gene due to lack of the chromatin-remodeling factor DDM1. EMBO J 26: $3641-3652$

\section{Sessa F, Mapelli M, Ciferri C, Tarricone C, Areces LB, Schneider TR, Stukenberg} PT, Musacchio A (2005) Mechanism of Aurora B activation by INCENP and inhibition by hesperadin. Mol Cell 18: 379-391

Tang A, Gao K, Chu L, Zhang R, Yang J, Zheng J (2017) Aurora kinases: novel therapy targets in cancers. Oncotarget 8: 23937-23954

Trivedi P, Stukenberg PT (2016) A Centromere-Signaling Network Underlies the 
bioRxiv preprint doi: https://doi.org/10.1101/2020.03.19.998880; this version posted March 20, 2020. The copyright holder for this preprint

(which was not certified by peer review) is the author/funder, who has granted bioRxiv a license to display the preprint in perpetuity. It is made available under aCC-BY-NC 4.0 International license.

Coordination among Mitotic Events. Trends Biochem Sci 41: 160-174

\section{Uren AG, Wong L, Pakusch M, Fowler KJ, Burrows FJ, Vaux DL, Choo KH} (2000) Survivin and the inner centromere protein INCENP show similar cell-cycle localization and gene knockout phenotype. Curr Biol 10: 1319-1328

Vader G, Kauw JJ, Medema RH, Lens SM (2006) Survivin mediates targeting of the chromosomal passenger complex to the centromere and midbody. EMBO Rep 7: 85-92

\section{Van Damme D, De Rybel B, Gudesblat G, Demidov D, Grunewald W, De Smet I,} Houben A, Beeckman T, Russinova E (2011) Arabidopsis $\alpha$ Aurora kinases function in formative cell division plane orientation. Plant Cell 23: 4013-4024

van der Horst A, Lens SM (2014) Cell division: control of the chromosomal passenger complex in time and space. Chromosoma 123: 25-42

van der Waal MS, Hengeveld RC, van der Horst A, Lens SM (2012) Cell division control by the Chromosomal Passenger Complex. Exp Cell Res 318: 1407-1420

Weimer AK, Demidov D, Lermontova I, Beeckman T, Van Damme D (2016) Aurora Kinases Throughout Plant Development. Trends Plant Sci 21: 69-79

Wijnker E, Schnittger A (2013) Control of the meiotic cell division program in plants. Plant Reprod 26: 143-158

\section{Xu Z, Ogawa H, Vagnarelli P, Bergmann JH, Hudson DF, Ruchaud S, Fukagawa} T, Earnshaw WC, Samejima K (2009) INCENP-aurora B interactions modulate kinase activity and chromosome passenger complex localization. J Cell Biol 187: 637-653

Yamanaka Y, Heike T, Kumada T, Shibata M, Takaoka Y, Kitano A, Shiraishi K, Kato T, Nagato M, Okawa K, Furushima K, Nakao K, Nakamura Y, Taketo MM, Aizawa S, Nakahata T (2008) Loss of Borealin/DasraB leads to defective cell proliferation, p53 accumulation and early embryonic lethality. Mech Dev 125: $441-450$

Zheng B, Chen X, McCormick S (2011) The anaphase-promoting complex is a dual integrator that regulates both MicroRNA-mediated transcriptional regulation of cyclin B1 and degradation of Cyclin B1 during Arabidopsis male gametophyte development. Plant Cell 23: 1033-1046 
Table 1. The genetic material generated in this study.

\begin{tabular}{|c|c|}
\hline Construct & Genetic background \\
\hline \multicolumn{2}{|l|}{ amiRNAi lines } \\
\hline 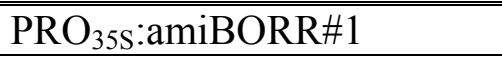 & Wild type \\
\hline $\mathrm{PRO}_{35 \mathrm{~S}}: \mathrm{amiBORR \# 2}$ & Wild type \\
\hline \multicolumn{2}{|l|}{ FP expression lines } \\
\hline \multirow[t]{2}{*}{ PRO ${ }_{\text {BORR:MGFP:BORR }}$} & borr-1 \\
\hline & PRORPS5A:TagRFP:TUA5 \\
\hline \multirow[t]{3}{*}{$\mathrm{PRO}_{\mathrm{BORR}}: \mathrm{BORR}: \mathrm{mGFP}$} & borr-1 \\
\hline & PRO $_{\text {RPS5A }}:$ TagRFP:TUA5 \\
\hline & $\mathrm{PRO}_{\mathrm{CENH} 3}:$ TagRFP:CENH3 \\
\hline \multirow[t]{2}{*}{$\mathrm{PRO}_{\mathrm{BORR}}: \mathrm{BORR}^{\mathrm{S} 214 \mathrm{~A}}: \mathrm{mGFP}$} & borr-1 \\
\hline & PRORPS5A:TagRFP:TUA5 \\
\hline \multirow[t]{2}{*}{$\mathrm{PRO}_{\text {BORR }}: \mathrm{BORR}^{\mathrm{S} 214 \mathrm{D}}: \mathrm{mGFP}$} & borr-1 \\
\hline & 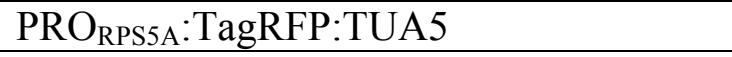 \\
\hline \multirow[t]{3}{*}{ PRO INCENP:mGFP:INCENP } & wyr-2 \\
\hline & PRORPS5A:TagRFP:TUA5 \\
\hline & PRO $_{\text {BORR:BORR:TagRFP }}$ \\
\hline PRO $_{\text {INCENP:INCENP:mGFP }}$ & wyr-2 \\
\hline \multirow[t]{4}{*}{ PRO $_{\text {AUR3 }}: A U R 3: m G F P$} & PRORPS5A:TagRFP:TUA5 \\
\hline & PRO $_{\text {RPS5A }}:$ TagRFP:TUA5 (amiBORR\#1-1) \\
\hline & PRO $_{\text {BORR:BORR:TagRFP }}$ \\
\hline & PRO INCENP:mRUBY3:INCENP $_{\text {INP }}$ \\
\hline $\begin{array}{l}\text { PRO }_{\text {CENH3 }}: \text { TagRFP:CENH3 } \\
\text { PRO }_{\text {RPS5A }}: \text { TagRFP:TUA5 }\end{array}$ & amiBORR\#1-1 \\
\hline \multicolumn{2}{|l|}{ GUS expression line } \\
\hline PRO $_{\text {BORR:BORR:GUS }}$ & Wild type \\
\hline
\end{tabular}




\section{Figure 1}

A

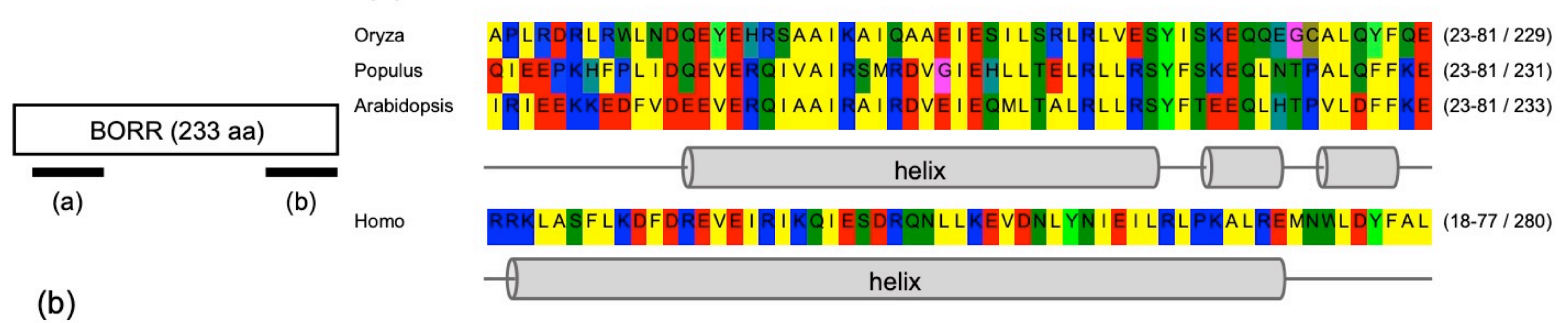

(a)

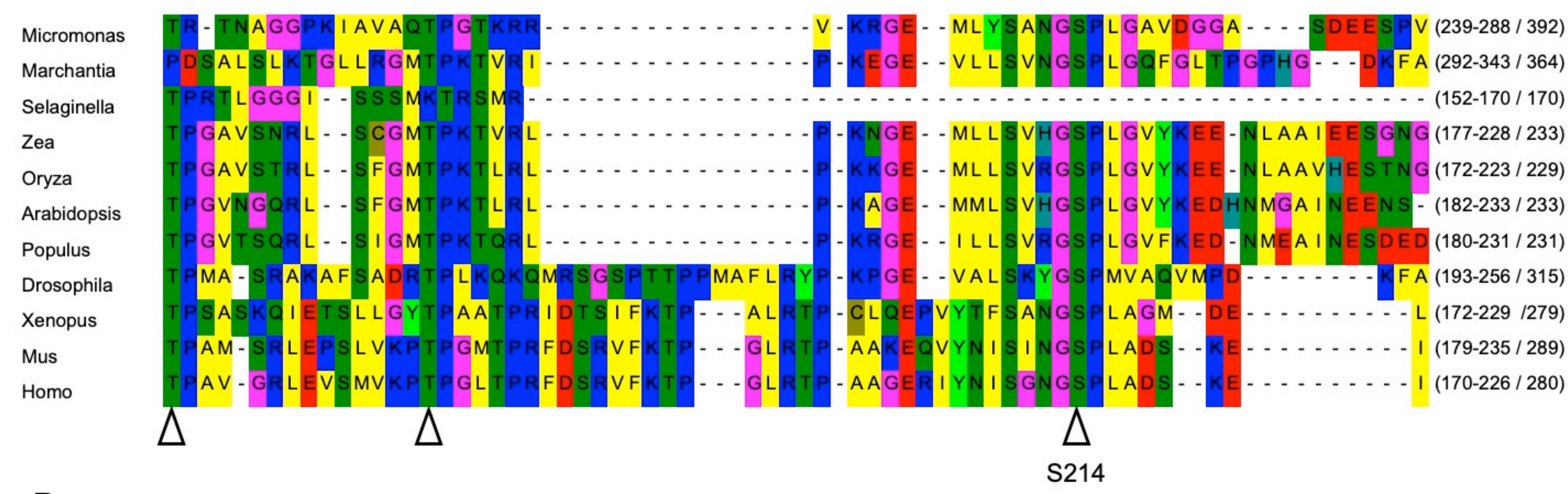

B

Micromonas

Marchantia

Selaginella

Zea

Oryza

Arabidopsis

Populus

Drosophila

Xenopus

Mus

Homo

S214

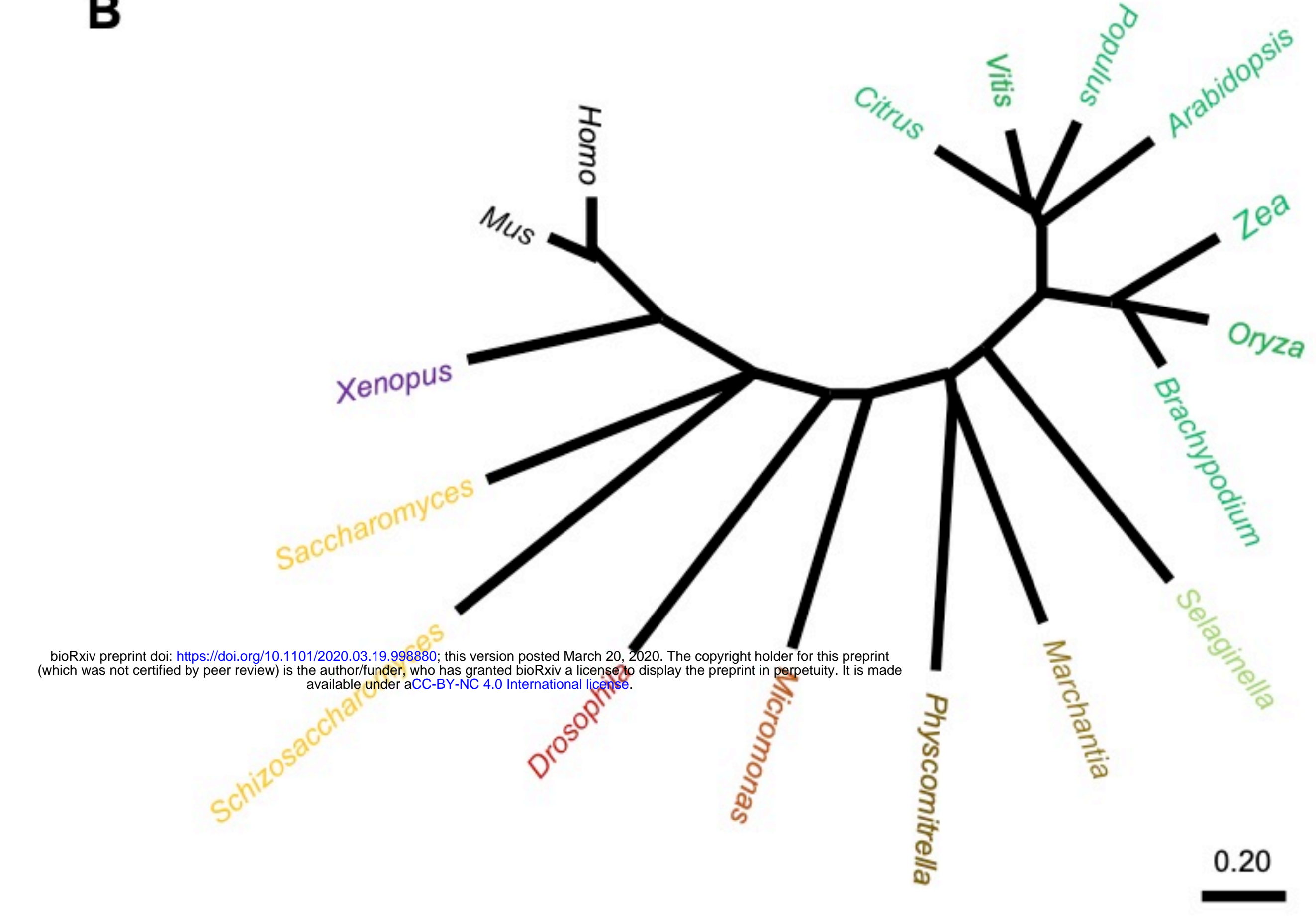

BOREALIN-RELATED (BORR) gene structure in plants. A, Protein sequence of BORR in Arabidopsis. Predictions of the N-terminal helix in BORR are shown in (a) and and alignment of the most sequence conserved region of the protein in (b). Arrow heads in (b) indicate the conserved CDK consensus sites. B, Phylogenetic analysis of the Borealin family in yeast, animals and plants. The tree was constructed using MEGA $X$ by the neighbor-joining method. 
A

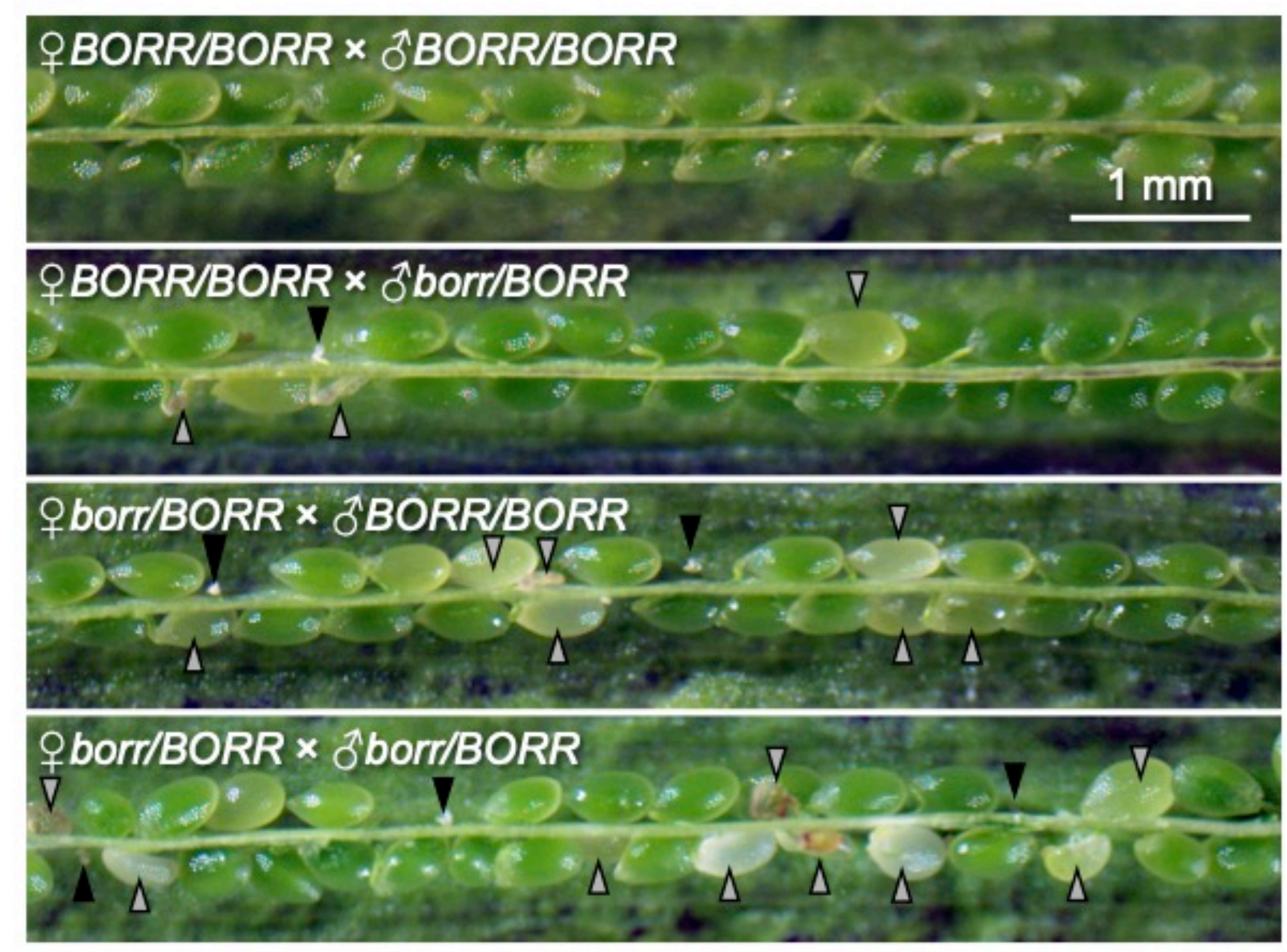

B

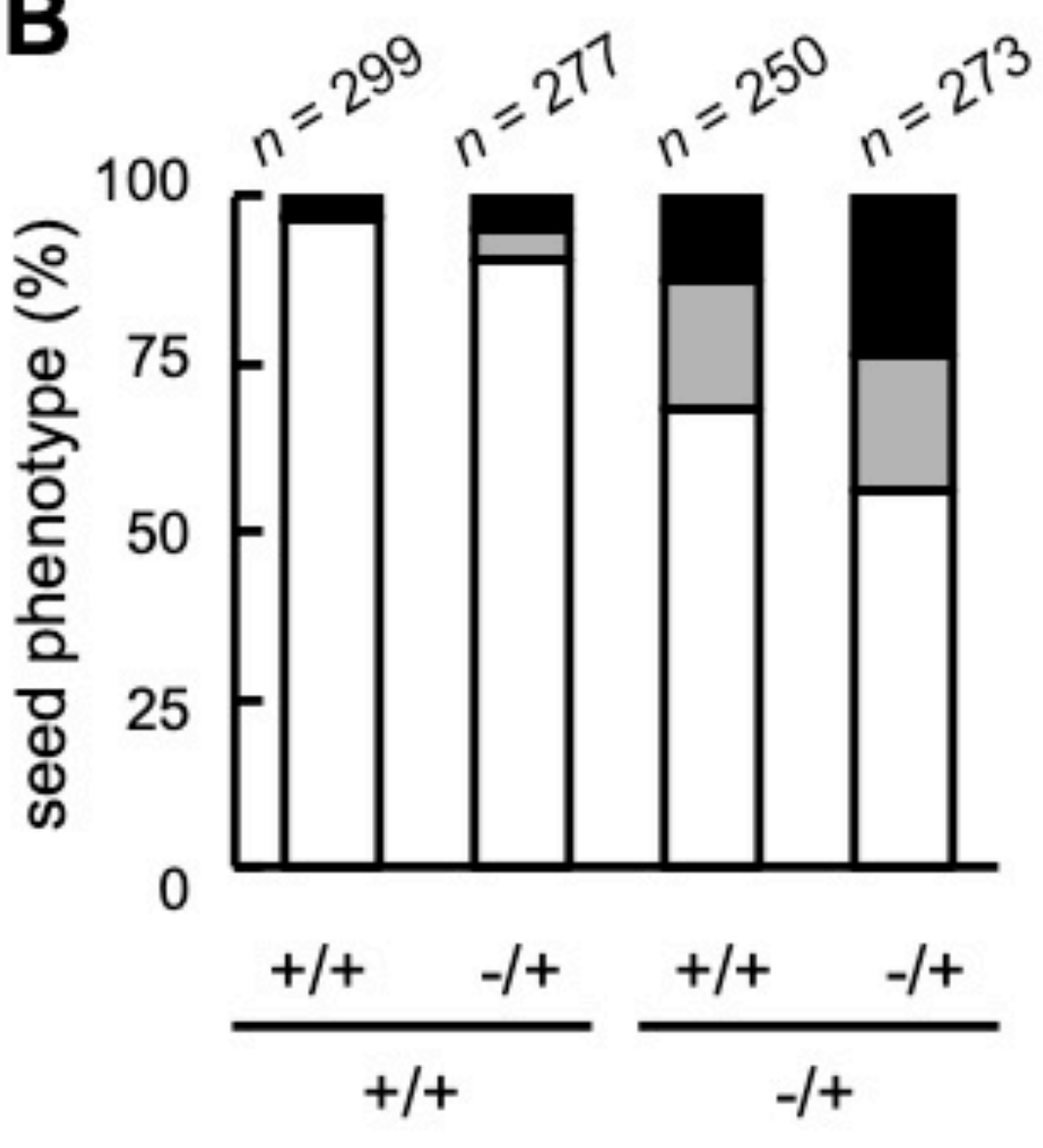

$\square$ normal seeds

$\square$ late aborted seeds

unfertilized ovules/early arrested seeds

\section{C}
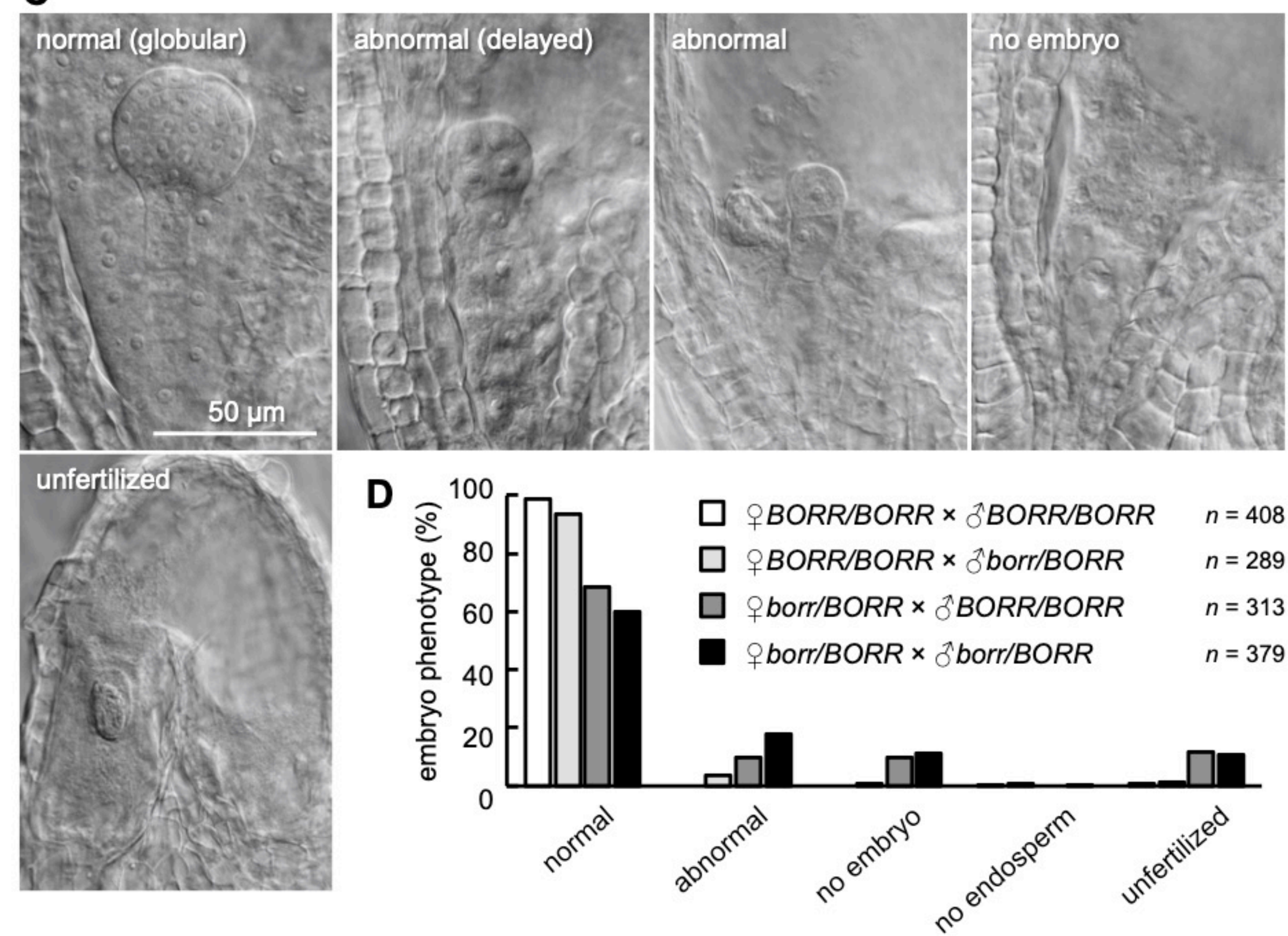

$B O R R_{\text {is }}$ required for seed development. A, Wildtype or heterozygous borr mutant plants pollinated with pollen from wildtype or heterozygous borr mutants. Black and gray arrowheads indicate tiny white ovules (unfertilized ovules/early arrested seeds) and collapsed brown seeds or seeds without green embryo (late aborted seeds), respectively. B, Proportion of the seed phenotypes shown in (A). Total number $(n)$ of seeds and ovules from five hand-pollinated siliques are shown in each cross. C, Seeds and ovules from the heterozygous borr siliques cleared in chloral hydrate solution. At the globular embryo stage, developing seeds with abnormal embryos, developing seeds with no embryo, and unfertilized ovules were observed. D, Classification of the embryo phenotype for each cross. Total number $(n)$ of developing seeds and unfertilized ovules from 6-8 hand-pollinated pistils are shown. 


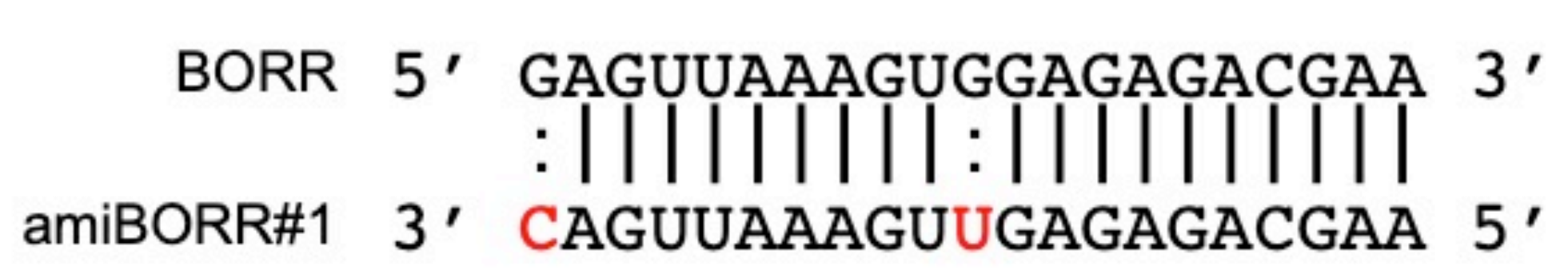

BORR 5' CUGAUAACCCACAGCUCGAUA ${ }^{\prime}$

C

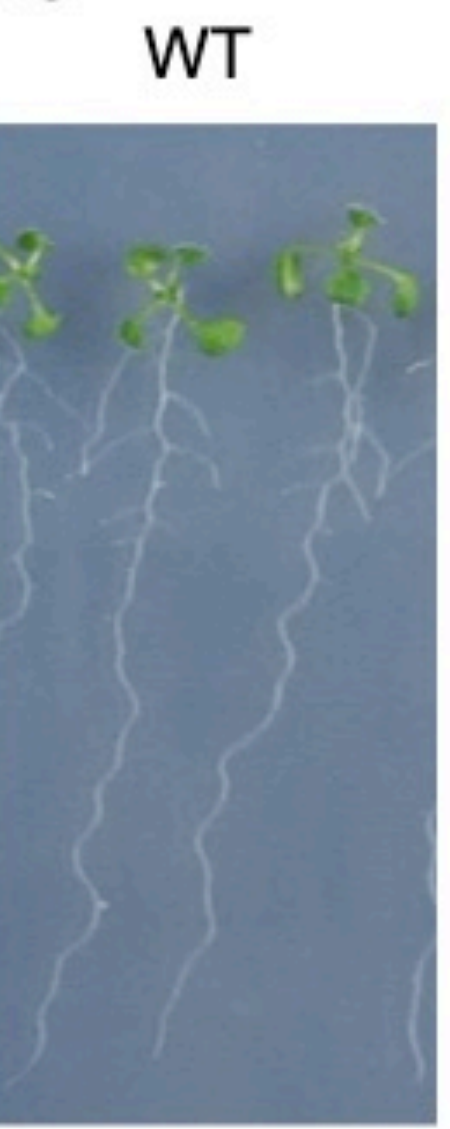

amiBORR\#1-1 amiBORR\#1-2 amiBORR\#2-1 amiBORR\#2-2
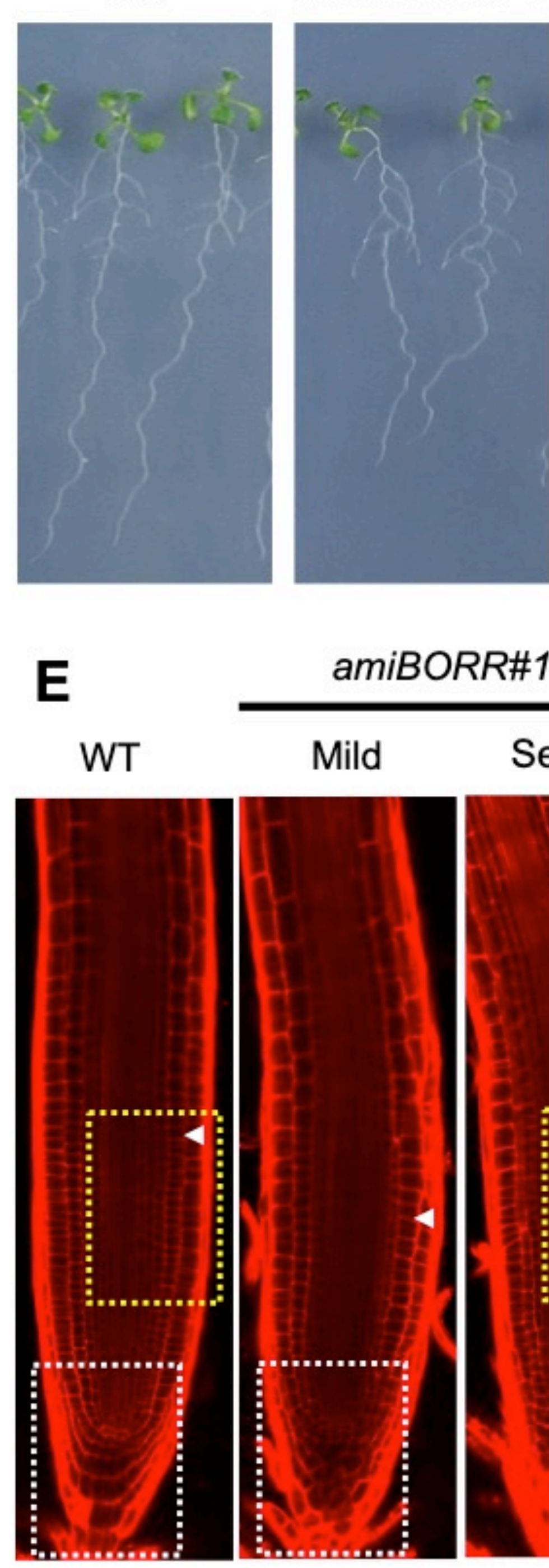

F

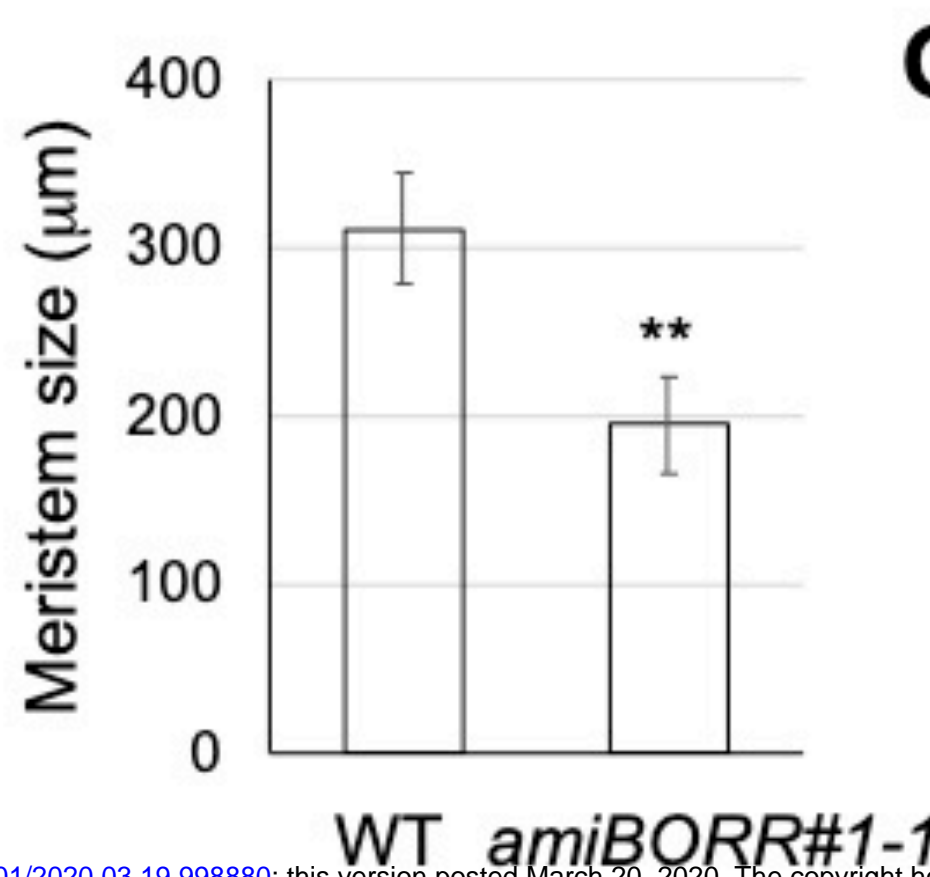

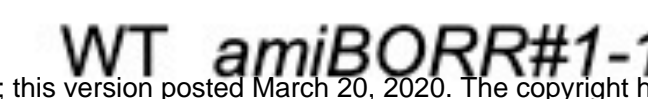
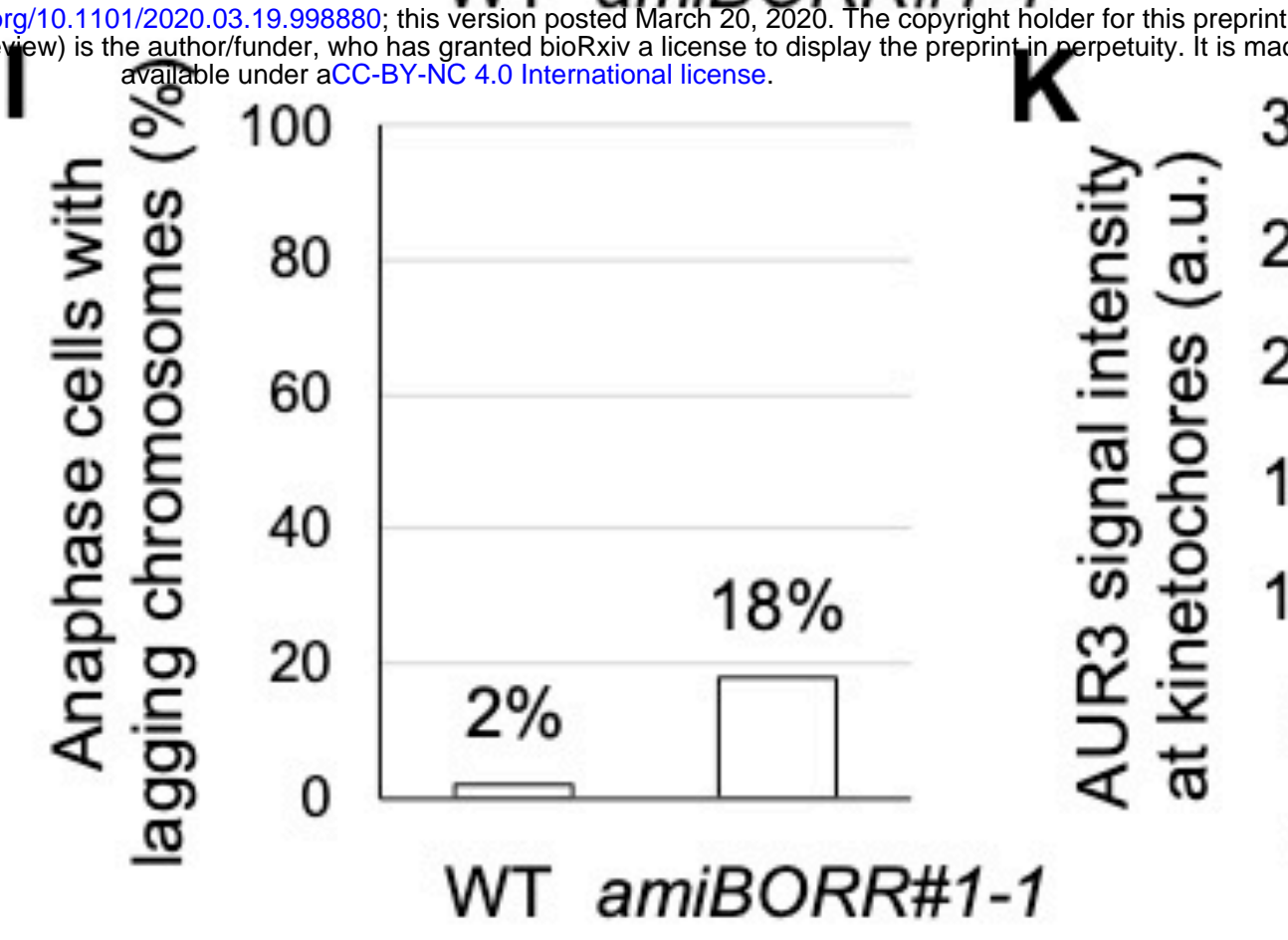

G $\frac{\underline{\underline{w}}}{\overline{\mathrm{o}}} 5$
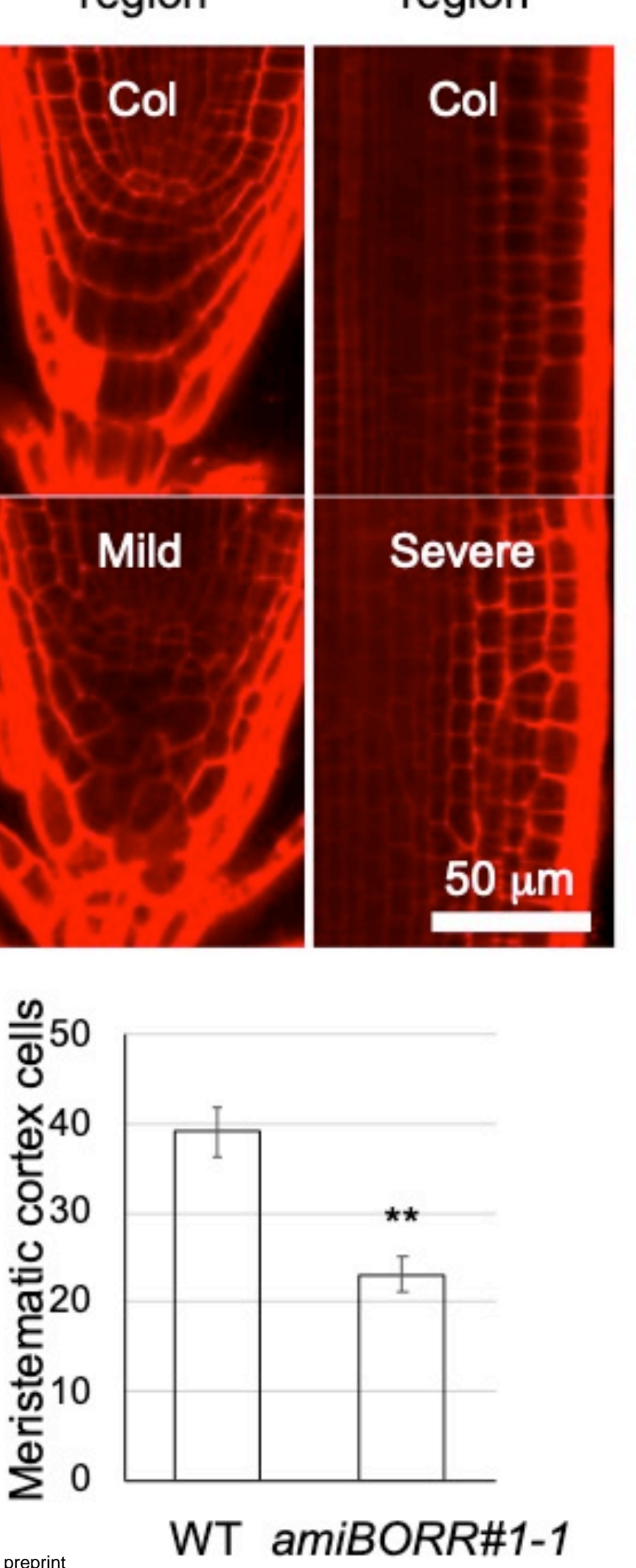

H

D

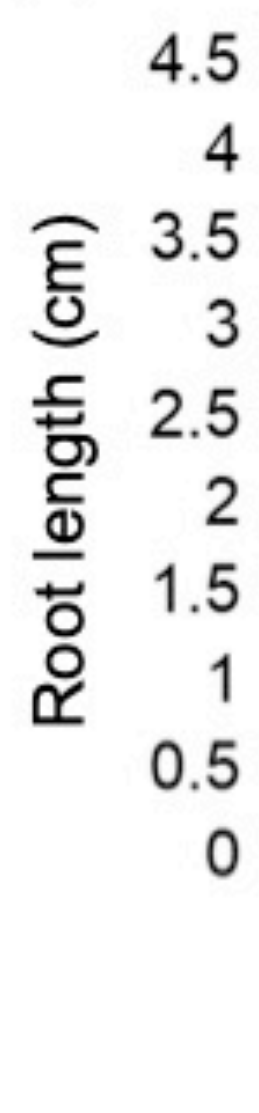

-WT

J

WT amiBORR\#1-1
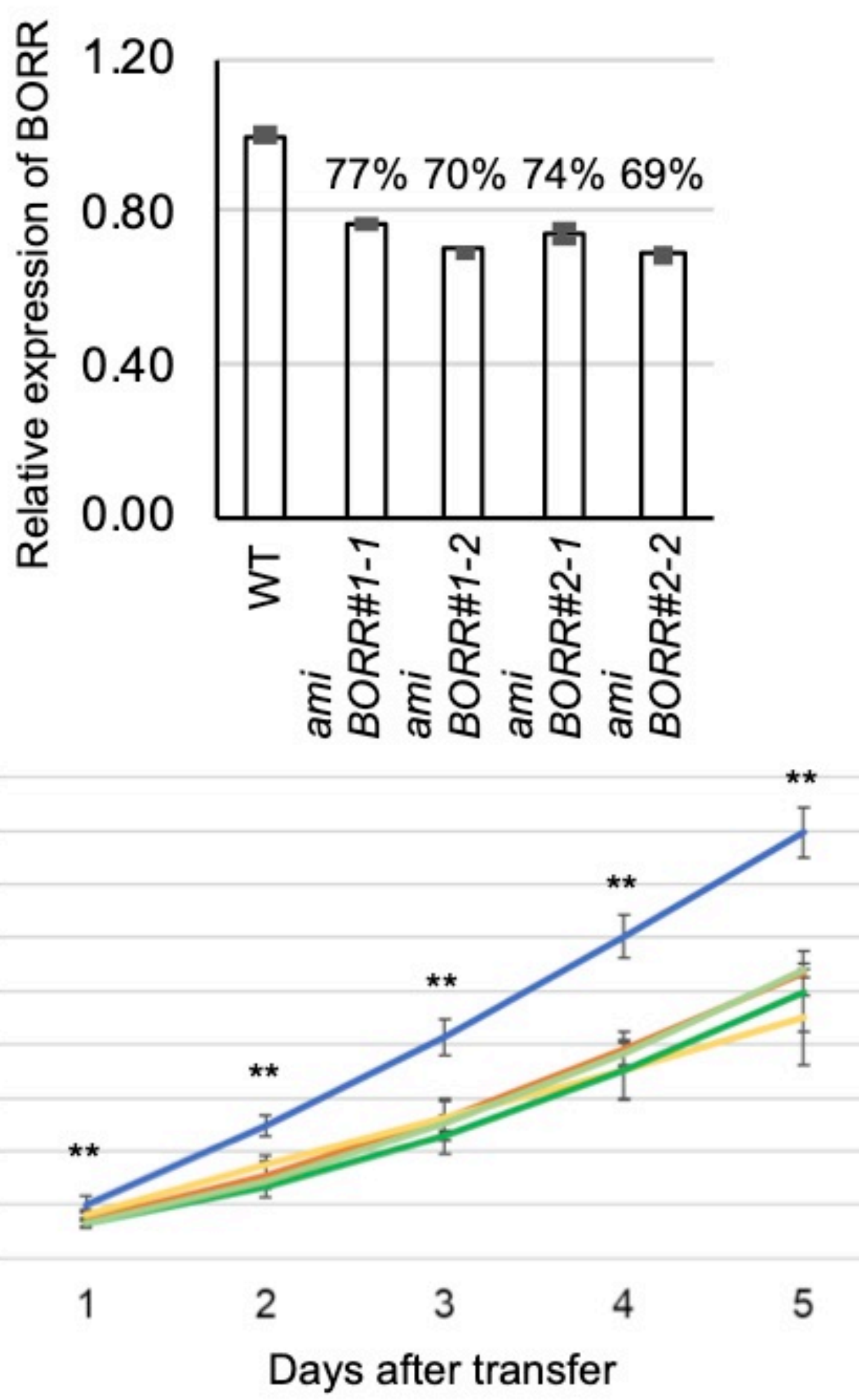

- amiBORR\#1-1 - amiBORR\#1-2
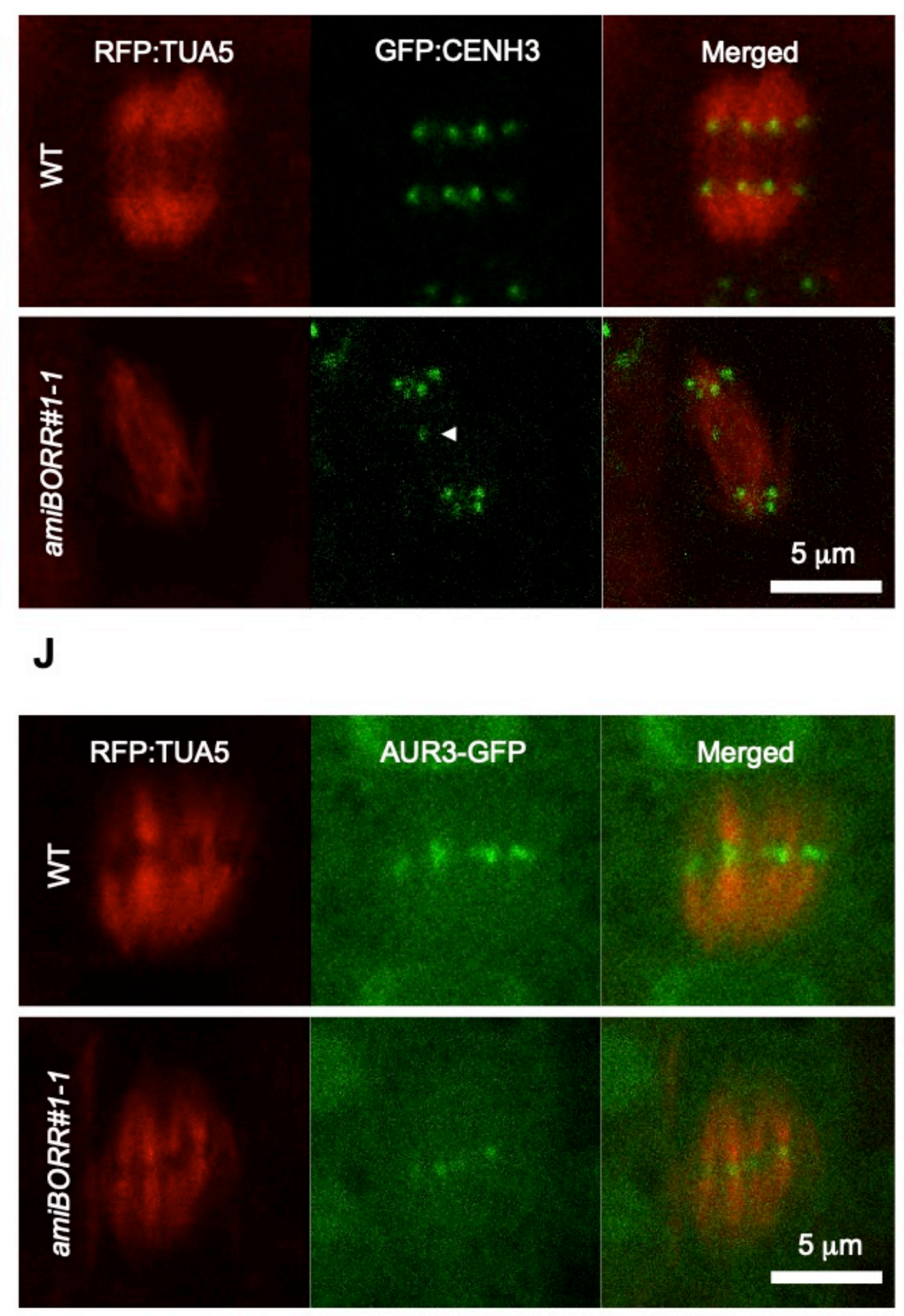

Phenotypical analysis of artificial miRNA-mediated BORR knockdown plants. A, Sequence alignments of artificial miRNAs and their target sites on BORR mRNA. B, Relative expression level of BORR in the amiBORR plants was confirmed by qRT-PCR analysis with three biological replicates. C, 9-day-old wild-type and amiBORR seedlings. D, Root growth measurements of the wildtype and amiBORR plants. 4-day-old seedlings were transferred to a MS plate and root lengths were measured for 5 days. ** $P<0.01$, Student's $t$-test. Error bars indicate SD $(n=10)$. E, Confocal images of 7-day-old wild-type and amiBORR\#1-1 roots stained with propidium iodide. amiBORR\#1-1 roots were categorized into 'Mild' and 'Severe' groups based on the phenotype. Arrows indicate the boundary between the dividing region and the elongation region of the root. The Panels Columella region and Dividing region show close-up views of the regions marked by white and yellow boxes, respectively. $F$ and $G$, Root meristem size ( $F)$ and number of meristematic cortex cells $(\mathrm{G}) .{ }^{* *} P<0.01$, Student's $t$-test. Error bars indicate SD $(n=15)$. H, Representative images of normally distributed and lagging chromosomes in 7-day-old WT and amiBORR\#1-1 root cells. Microtubules and centromeres are visualized by TagRFP:TUA5 and GFP:CENH3, respectively. The arrow indicates a lagging chromosome. I, Frequency of lagging chromosomes in anaphase in $(\mathrm{H})$. Error bars indicate SD $(n=50)$. J, Representative images of AUR3 accumulation levels at kinetochores in 7-day-old wild-type and amiBORR\#1-1 root cells. Microtubules and AUR3 are visualized by TagRFP:TUA5 and AUR3:GFP, respectively. K, AUR3 signal intensity at kinetochores in (J). 40 AUR3-GFP signals at kinetochores from 10 cells were measured. Median (center line), IQR (box), 1.5 x IQR (error bars), and outliers (circles) are shown. ${ }^{* *} P<0.01$, Student's $t$-test. Error bars indicate SD. 


\section{Figure 4}

A

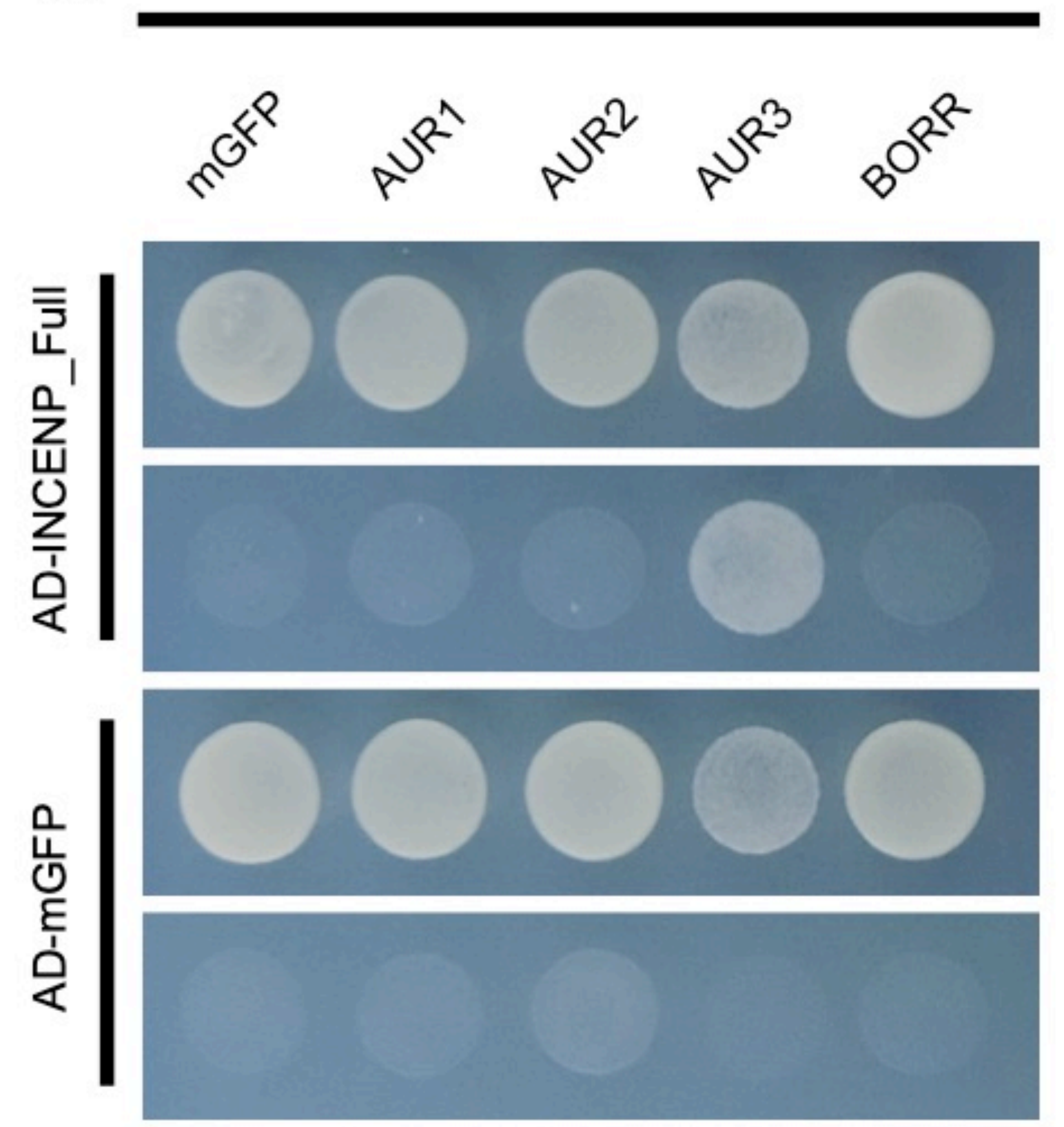

BD

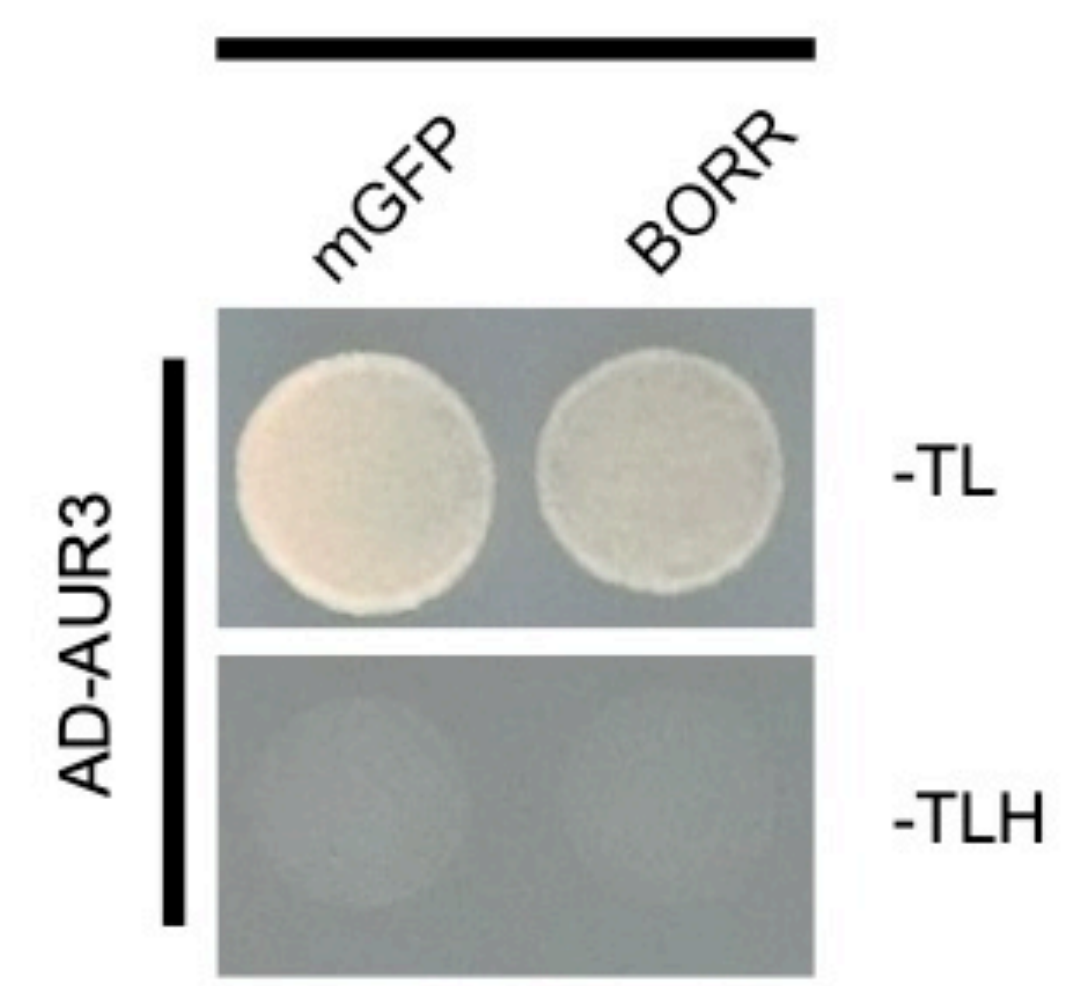

B

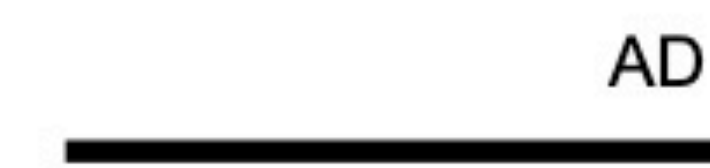

$-\mathrm{TL}$

-TLH

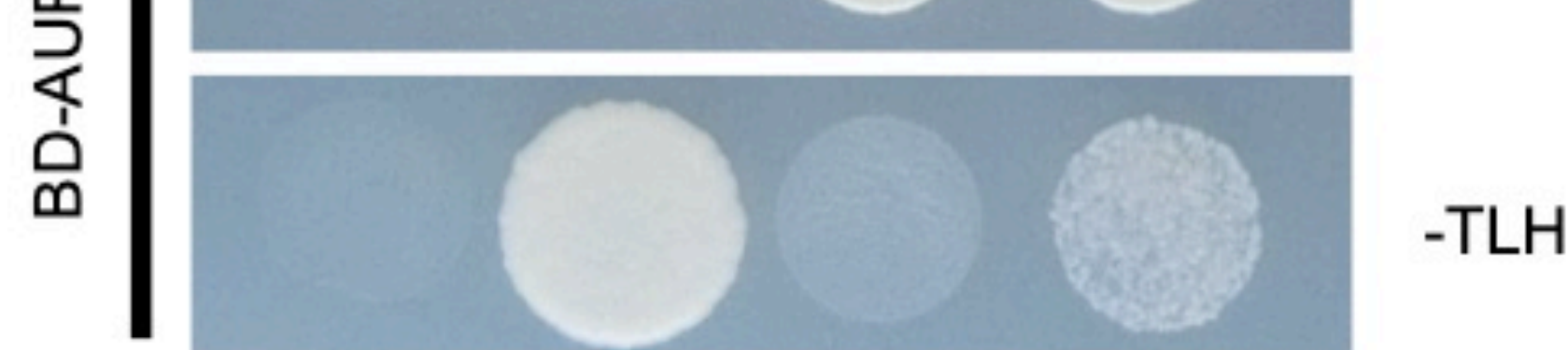

$-T L$

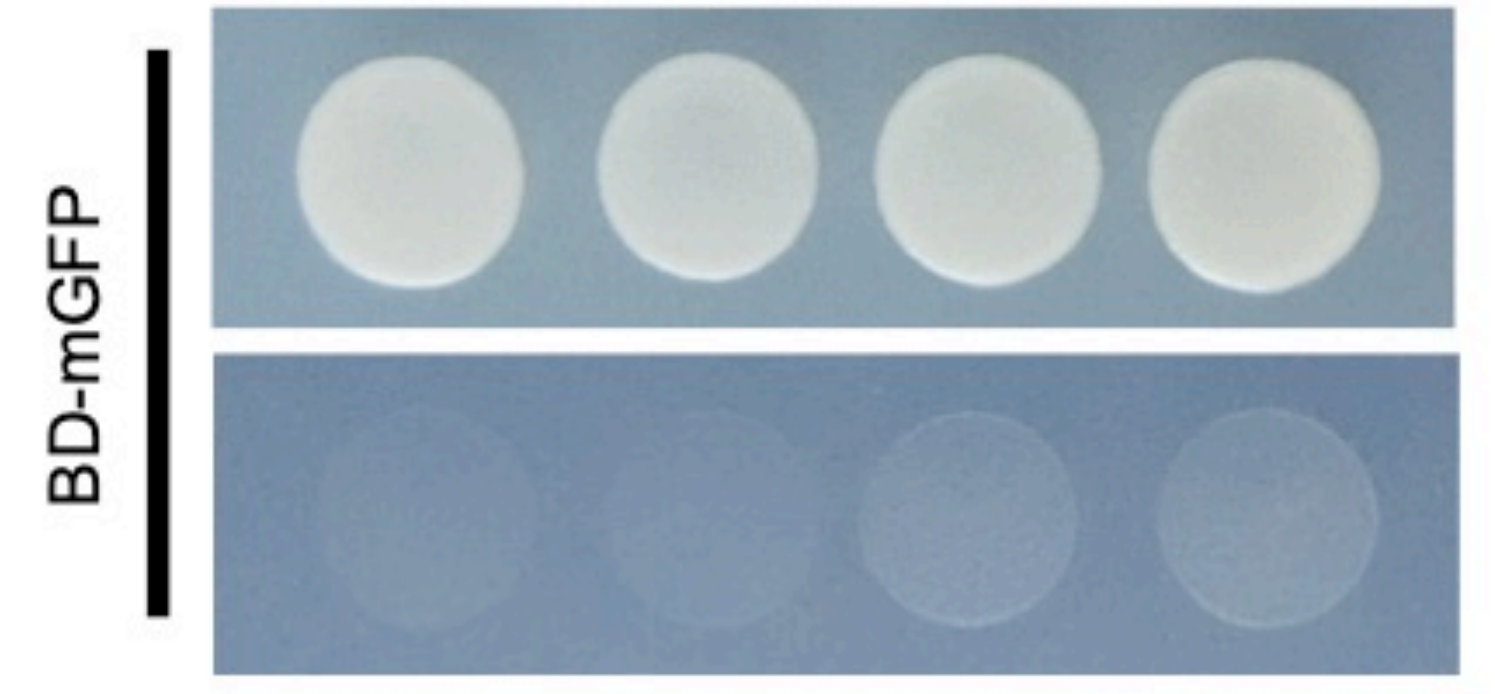

$-\mathrm{TL}$

-TLH

C

BORR:RFP

Col mGFP:INCENP mGFP

Input

IP

$\alpha$ GFP

Interaction among the CPC components. A, Interaction among the CPC components were revealed by yeast two-hybrid assays. B, Interaction between AUR3 and various regions of INCENP or IN-boxmutated INCENP. Monomeric GFP (mGFP) was used as a negative control. Each strain was spotted on SD plates without tryptophan and leucine (-TL; control media) or without tryptophan, leucine, and histidine (-TLH; selection media) and photographed after incubation at $30^{\circ} \mathrm{C}$ for 2 days. C, Coimmunoprecipitation of INCENP with BORR. 7-day-old Arabidopsis seedlings expressing BORR:RFP and mGFP:INCENP or BORR:RFP and mGFP were used for IP with an anti-GFP antibody. Both input and IP fraction were subjected to immunoblotting with an anti-RFP antibody. The asterisk on the input

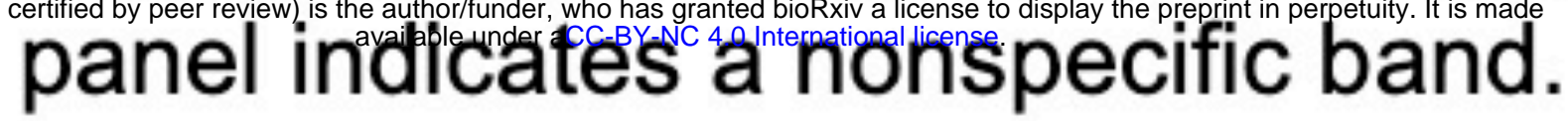




\section{Figure 5}
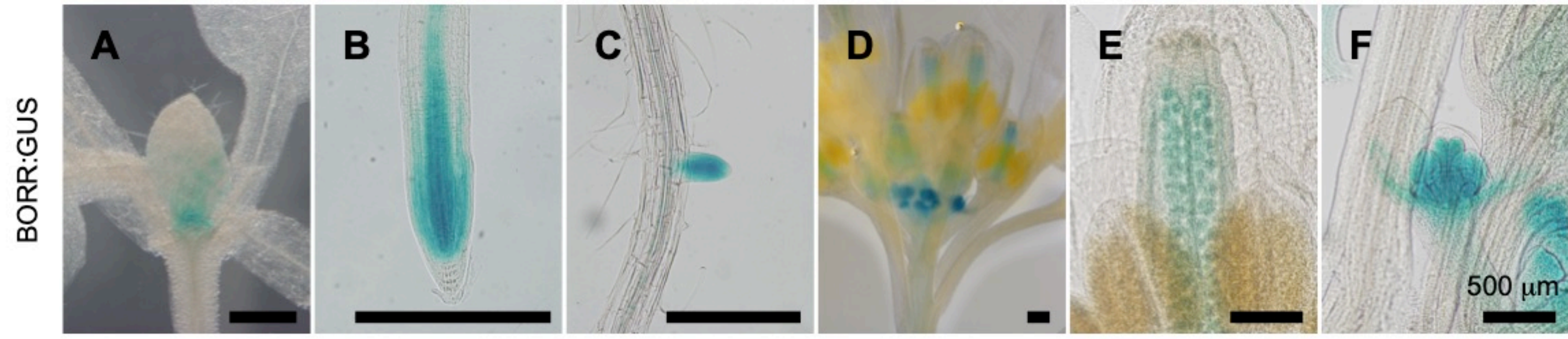

G

NEB

Prometaphase

Anaphase onset

Anaphase

Telophase
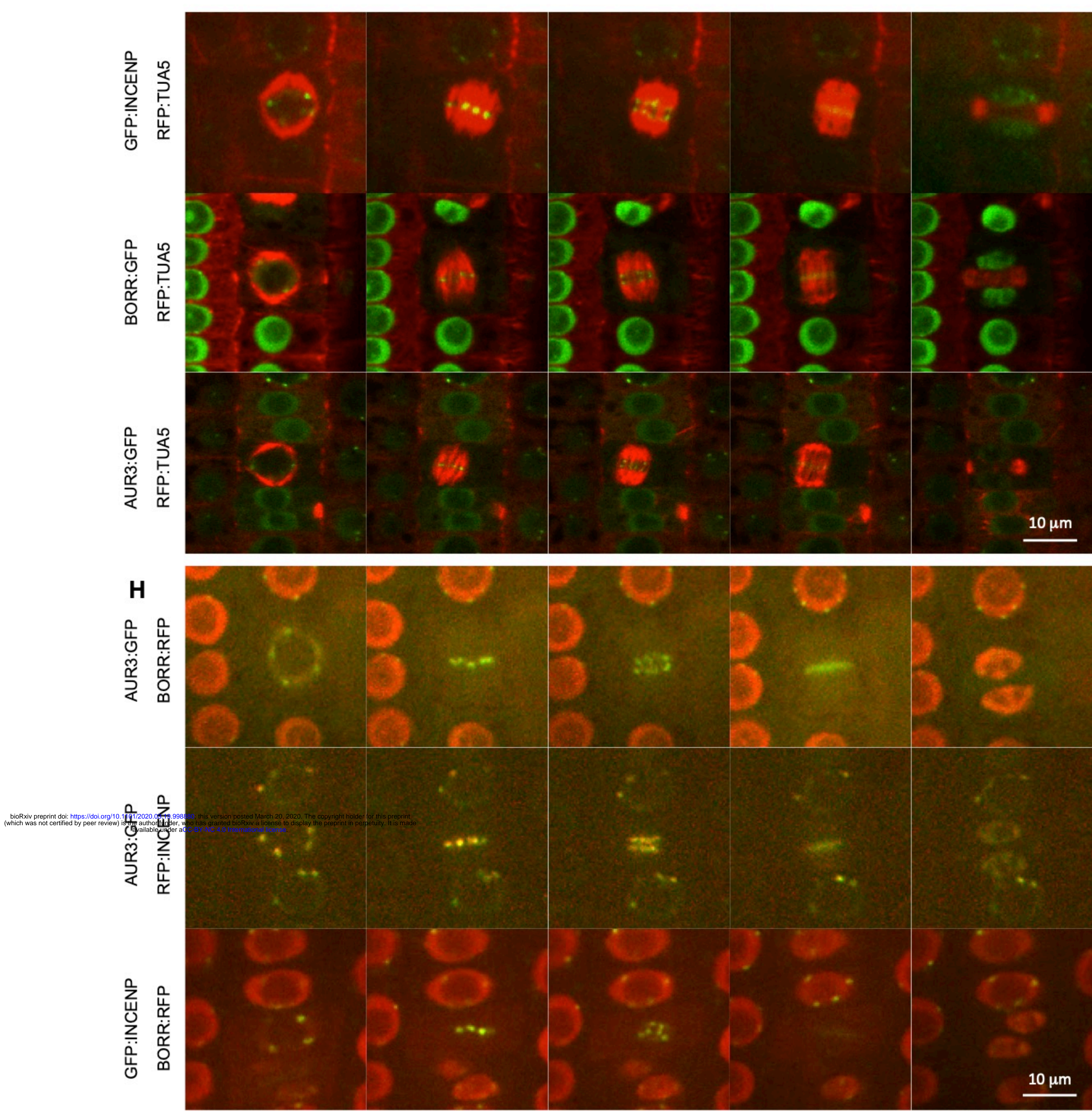

Expression and subcellular localization of CPC components. A to $F$, Expression pattern of BORR:GUS in the shoot $(A)$, root $(B)$, lateral roots $(C)$, inflorescence $(D)$, ovules $(E)$, and young flower buds $(F)$. 10-dayold seedlings were used for $(A)$ to $(C)$, and 4-week old plants were used for $(D)$ to $(F)$. Three independent transgenic lines were analyzed and representative images are shown. G, Subcellular localization of GFP:INCENP, BORR:GFP, and AUR3:GFP during the cell cycle. Each reporter line was crossed with TagRFP:TUA5-expressing plants to visualize microtubule structures. $\mathrm{H}$, Co-localization of the CPC components during the cell cycle. For live imaging of $(G)$ and $(H)$, root tips of 5-day-old seedlings were used. 


\section{Figure 6}
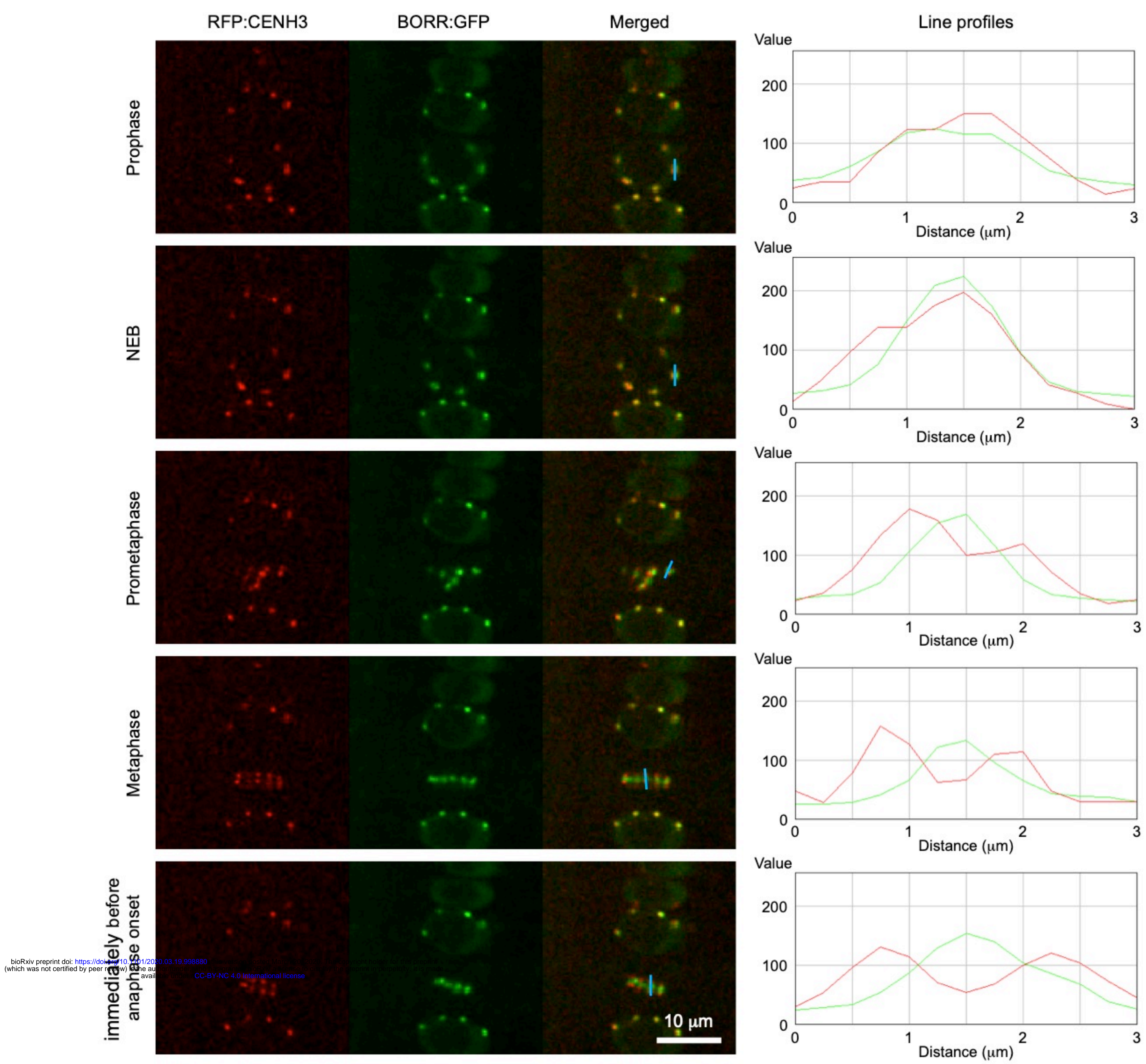

CPC localizes to inner centromeres. Localization of the CPC from prophase to immediately before anaphase onset. Inner kinetochores and CPC complexes are visualized by TagRFP:CENH3 and BORR:GFP, respectively. For live cell imaging, root tips of 5-day-old seedlings were used. Blue bar indicates the position where the line profiles were obtained. 


\section{Figure 7}

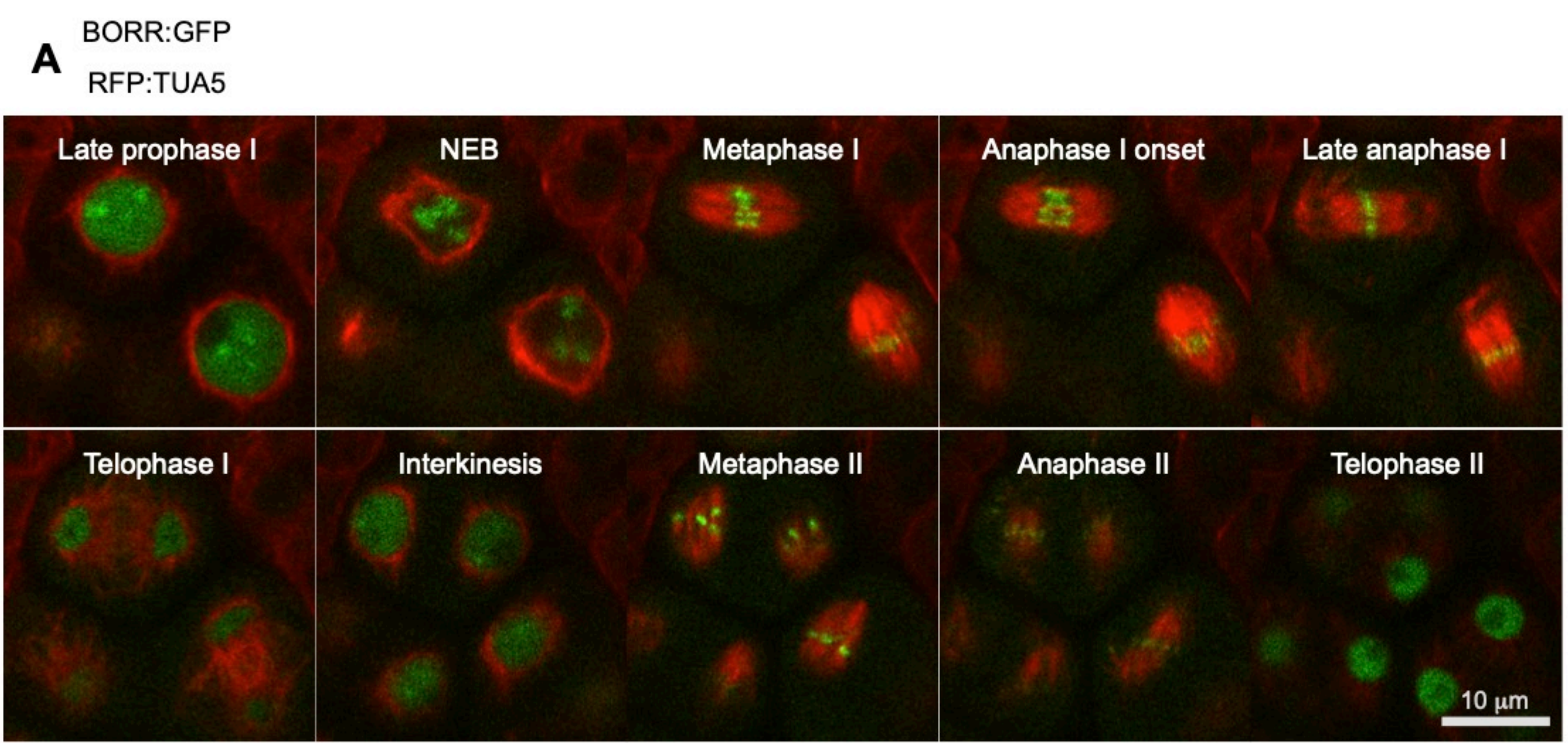

B GFP-INCENP

RFP:TUA5

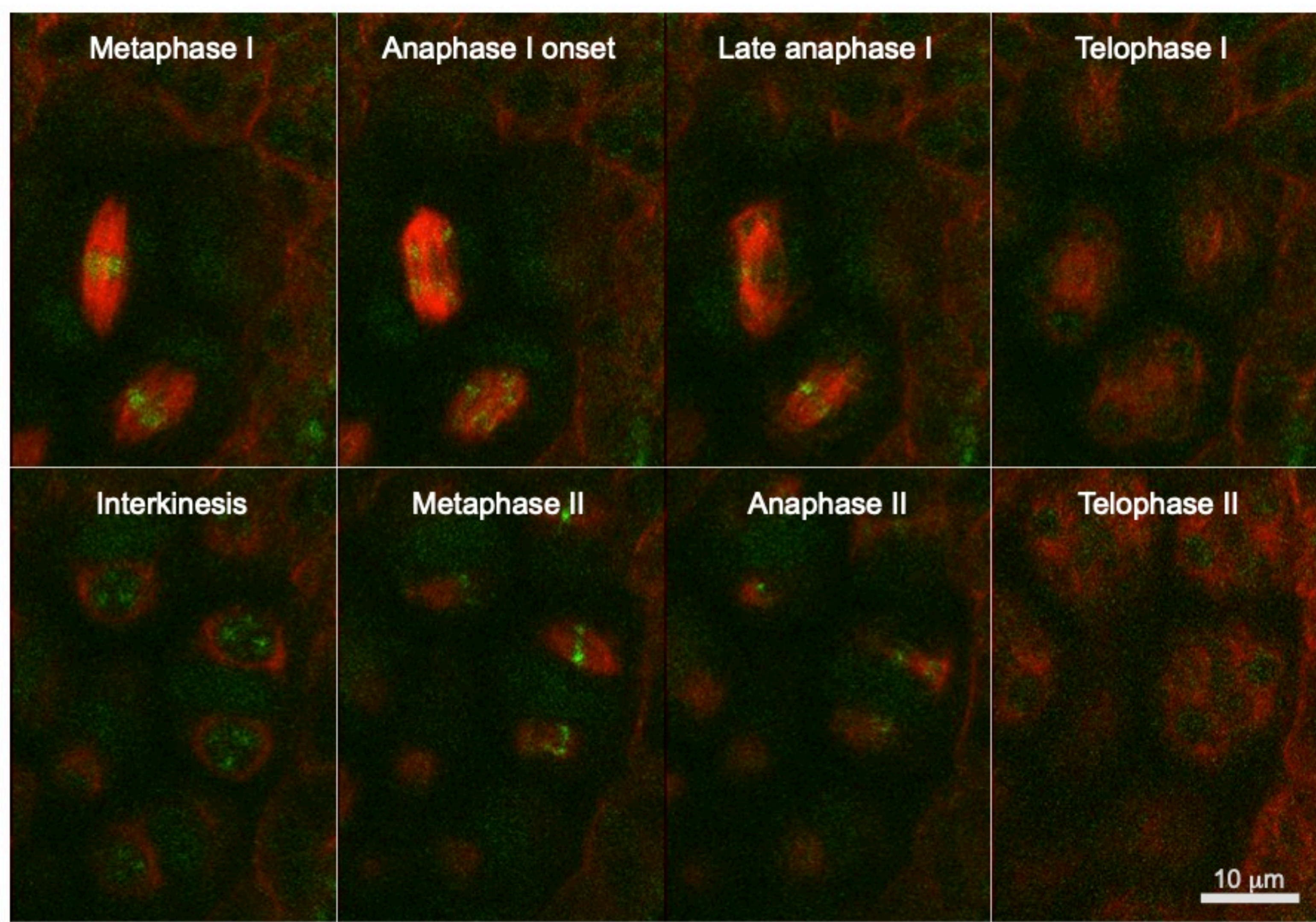

Subcellular localizatization of CPC components in meiosis. A and B, Subcellular localization of BORR:GFP (A) and GFP:INCENP (B) during meiosis. Each reporter line was crossed with TagRFP:TUA5-expressing plants to visualize the microtubule structures. For live imaging of $(A)$ and $(B)$, flower buds of 1-month-old plants were used. 


\section{Parsed Citations}

Adams RR, Wheatley SP, Gouldsworthy AM, Kandels-Lewis SE, Carmena M, Smythe C, Gerloff DL, Earnshaw WC (2000) INCENP binds the Aurora-related kinase ARK2 and is required to target it to chromosomes, the central spindle and cleavage furrow. Curr Biol 10: 1075-1078

Pubmed: Author and Title

Google Scholar: Author Only Title Only Author and Title

Barrett RM, Colnaghi R, Wheatley SP (2011) Threonine 48 in the BIR domain of survivin is critical to its mitotic and anti-apoptotic activities and can be phosphorylated by CK2 in vitro. Cell Cycle 10: 538-548

Pubmed: Author and Title

Google Scholar: Author Only Title Only Author and Title

Bekier ME, Mazur T, Rashid MS, Taylor WR (2015) Borealin dimerization mediates optimal CPC checkpoint function by enhancing localization to centromeres and kinetochores. Nat Commun 6: 6775

Pubmed: Author and Title

Google Scholar: Author Only Title Only Author and Title

Boruc J, Deng X, Mylle E, Besbrugge N, Van Durme M, Demidov D, Tomaštíková ED, Tan TC, Vandorpe M, Eeckhout D, Beeckman T, Nowack MK, De Jaeger G, Lin H, Liu B, Van Damme D (2019) TPX2-LIKE PROTEIN3 Is the Primary Activator of $\alpha$-Aurora Kinases and Is Essential for Embryogenesis. Plant Physiol 180: 1389-1405

Pubmed: Author and Title

Google Scholar: Author Only Title Only Author and Title

Bouyer D, Heese M, Chen P, Harashima H, Roudier F, Grüttner C, Schnittger A(2018) Genome-wide identification of RETINOBLASTOMARELATED 1 binding sites in Arabidopsis reveals novel DNA damage regulators. PLoS Genet 14: e1007797

Pubmed: Author and Title

Google Scholar: Author Only Title Only Author and Title

Cam H, Balciunaite E, Blais A, Spektor A, Scarpulla RC, Young R, Kluger Y, Dynlacht BD (2004) Acommon set of gene regulatory networks links metabolism and growth inhibition. Mol Cell 16: 399-411

Pubmed: Author and Title

Google Scholar: Author Only Title Only Author and Title

Carbonell A, Takeda A, Fahlgren N, Johnson SC, Cuperus JT, Carrington JC (2014) New generation of artificial MicroRNAand synthetic trans-acting small interfering RNA vectors for efficient gene silencing in Arabidopsis. Plant Physiol 165: 15-29

Pubmed: Author and Title

Google Scholar: Author Only Title Only Author and Title

Carmena M, Wheelock M, Funabiki H, Earnshaw WC (2012) The chromosomal passenger complex (CPC): from easy rider to the godfather of mitosis. Nat Rev Mol Cell Biol 13: 789-803

Pubmed: Author and Title

Google Scholar: Author Only Title Only Author and Title

Cutts SM, Fowler KJ, Kile BT, Hii LL, O'Dowd RA, Hudson DF, Saffery R, Kalitsis P, Earle E, Choo KH (1999) Defective chromosome segregation, microtubule bundling and nuclear bridging in inner centromere protein gene (Incenp)-disrupted mice. Hum Mol Genet 8: 1145-1155

Pubmed: Author and Title

Google Scholar: Author Only Title Only Author and Title

Czechowski T, Stitt M, Altmann T, Udvardi MK, Scheible WR (2005) Genome-wide identification and testing of superior reference genes for transcript normalization in Arabidopsis. Plant Physiol 139: 5-17

Pubmed: Author and Title

Google Scholar: Author Only Title Only Author and Title

Date D, Dreier MR, Borton MT, Bekier ME, Taylor WR (2012) Effects of phosphatase and proteasome inhibitors on Borealin phosphorylation and degradation. J Biochem 151: 361-369

Pubmed: Author and Title

Google Scholar: Author Only Title Only Author and Title

Date DA, Jacob CJ, Bekier ME, Stiff AC, Jackson MW, Taylor WR (2007) Borealin is repressed in response to p53/Rb signaling. Cell Biol Int 31: 1470-1481

Pubmed: Author and Title

Google Scholar: Author Only Title Only Author and Title

Demidov D, Lermontova I, Weiss O, Fuchs J, Rutten T, Kumke K, Sharbel TF, Van Damme D, De Storme N, Geelen D, Houben A(2014) Altered expression of Aurora kinases in Arabidopsis results in aneu- and polyploidization. Plant J 80: 449-461

Pubmed: Author and Title

Google Scholar: Author Only Title Only Author and Title

Demidov D, Van Damme D, Geelen D, Blattner FR, Houben A(2005) Identification and dynamics of two classes of aurora-like kinases in Arabidopsis and other plants. Plant Cell 17: 836-848

Pubmed: Author and Title

Google Scholar: Author Only Title Only Author and Title 

available under aCC-BY-NC 4.0 International license.

Dissmeyer N, Schnittger A(2011) Use of phospho-site substitutions to analyze the biological relevance of phosphorylation events in regulatory networks. Methods Mol Biol 779: 93-138

Pubmed: Author and Title

Google Scholar: Author Only Title Only Author and Title

Fauser F, Schiml S, Puchta H (2014) Both CRISPR/Cas-based nucleases and nickases can be used efficiently for genome engineering in Arabidopsis thaliana. Plant J 79: 348-359

Pubmed: Author and Title

Google Scholar: Author Only Title Only Author and Title

Goldenson B, Crispino JD (2015) The aurora kinases in cell cycle and leukemia. Oncogene 34: 537-545

Pubmed: Author and Title

Google Scholar: Author Only Title Only Author and Title

Goto H, Kiyono T, Tomono Y, Kawajiri A, Urano T, Furukawa K, Nigg EA, Inagaki M (2006) Complex formation of PIk1 and INCENP required for metaphase-anaphase transition. Nat Cell Biol 8: 180-187

Pubmed: Author and Title

Google Scholar: Author Only Title Only Author and Title

Gruss OJ, Vernos I (2004) The mechanism of spindle assembly: functions of Ran and its target TPX2. J Cell Biol 166: $949-955$

Pubmed: Author and Title

Google Scholar: Author Only Title Only Author and Title

Haughn GW, Somerville C (1986) Sulfonylurea-resistant mutants of Arabidopsis thaliana. Molecular and General Genetics MGG 204: 430-434

Pubmed: Author and Title

Google Scholar: Author Only Title Only Author and Title

Hindriksen S, Lens SMA, Hadders MA(2017) The Ins and Outs of Aurora B Inner Centromere Localization. Front Cell Dev Biol 5: 112

Pubmed: Author and Title

Google Scholar: Author Only Title Only Author and Title

Honda R, Körner R, Nigg EA(2003) Exploring the functional interactions between Aurora B, INCENP, and survivin in mitosis. Mol Biol Cell 14: 3325-3341

Pubmed: Author and Title

Google Scholar: Author Only Title Only Author and Title

Jeyaprakash AA, Klein UR, Lindner D, Ebert J, Nigg EA, Conti E (2007) Structure of a Survivin-Borealin-INCENP core complex reveals how chromosomal passengers travel together. Cell 131: 271-285

Pubmed: Author and Title

Google Scholar: Author Only Title Only Author and Title

Kaur H, Bekier ME, Taylor WR (2010) Regulation of Borealin by phosphorylation at serine 219. J Cell Biochem 111: 1291-1298

Pubmed: Author and Title

Google Scholar: Author Only Title Only Author and Title

Kawabe A, Matsunaga S, Nakagawa K, Kurihara D, Yoneda A, Hasezawa S, Uchiyama S, Fukui K (2005) Characterization of plant Aurora kinases during mitosis. Plant Mol Biol 58: 1-13

Pubmed: Author and Title

Google Scholar: Author Only Title Only Author and Title

Kelly AE, Ghenoiu C, Xue JZ, Zerhut C, Kimura H, Funabiki H (2010) Survivin reads phosphorylated histone H3 threonine 3 to activate the mitotic kinase Aurora B. Science 330: 235-239

Pubmed: Author and Title

Google Scholar: Author Only Title Only Author and Title

Kirioukhova O, Johnston AJ, Kleen D, Kägi C, Baskar R, Moore JM, Bäumlein H, Gross-Hardt R, Grossniklaus U (2011) Female gametophytic cell specification and seed development require the function of the putative Arabidopsis INCENP ortholog WYRD.

Development 138: 3409-3420

Pubmed: Author and Title

Google Scholar: Author Only Title Only Author and Title

Kitagawa M, Lee SH (2015) The chromosomal passenger complex (CPC) as a key orchestrator of orderly mitotic exit and cytokinesis.

Front Cell Dev Biol 3: 14

Pubmed: Author and Title

Google Scholar: Author Only Title Only Author and Title

Komaki S, Schnittger A(2016) The spindle checkpoint in plants-a green variation over a conserved theme. Curr Opin Plant Biol 34: 8491

Pubmed: Author and Title

Google Scholar: Author Only Title Only Author and Title

Komaki S, Schnittger A(2017) The Spindle Assembly Checkpoint in Arabidopsis Is Rapidly Shut Off during Severe Stress. Dev Cell 43: 172-185.e5 
Google Scholar: Author Only Title Only Author and Title

Kozgunova E, Suzuki T, Ito M, Higashiyama T, Kurihara D (2016) Haspin has Multiple Functions in the Plant Cell Division Regulatory Network. Plant Cell Physiol 57: 848-861

Pubmed: Author and Title

Google Scholar: Author Only Title Only Author and Title

Kufer TA, Silljé HH, Körner R, Gruss OJ, Meraldi P, Nigg EA(2002) Human TPX2 is required for targeting Aurora-Akinase to the spindle. J Cell Biol 158: 617-623

Pubmed: Author and Title

Google Scholar: Author Only Title Only Author and Title

Kurihara D, Matsunaga S, Kawabe A, Fujimoto S, Noda M, Uchiyama S, Fukui K (2006) Aurora kinase is required for chromosome segregation in tobacco BY-2 cells. Plant J 48: 572-580

Pubmed: Author and Title

Google Scholar: Author Only Title Only Author and Title

Lee KH, Avci U, Qi L, Wang H (2019) The a-Aurora Kinases Function in Vascular Development in Arabidopsis. Plant Cell Physiol 60: 188-201

Pubmed: Author and Title

Google Scholar: Author Only Title Only Author and Title

London N, Biggins S (2014) Signalling dynamics in the spindle checkpoint response. Nat Rev Mol Cell Biol 15: $736-747$

Pubmed: Author and Title

Google Scholar: Author Only Title Only Author and Title

Lu LY, Wood JL, Ye L, Minter-Dykhouse K, Saunders TL, Yu X, Chen J (2008) Aurora A is essential for early embryonic development and tumor suppression. J Biol Chem 283: 31785-31790

Pubmed: Author and Title

Google Scholar: Author Only Title Only Author and Title

Müller S, Jürgens G (2016) Plant cytokinesis-No ring, no constriction but centrifugal construction of the partitioning membrane. Semin

Cell Dev Biol 53: 10-18

Pubmed: Author and Title

Google Scholar: Author Only Title Only Author and Title

Nakagawa T, Suzuki T, Murata S, Nakamura S, Hino T, Maeo K, Tabata R, Kawai T, Tanaka K, Niwa Y, Watanabe Y, Nakamura K, Kimura $\mathrm{T}$, Ishiguro S (2007) Improved Gateway binary vectors: high-performance vectors for creation of fusion constructs in transgenic analysis of plants. Biosci Biotechnol Biochem 71: 2095-2100

Pubmed: Author and Title

Google Scholar: Author Only Title Only Author and Title

Nakajima Y, Cormier A Tyers RG, Pigula A, Peng Y, Drubin DG, Barnes G (2011) Ipl1/Aurora-dependent phosphorylation of Sli15/INCENP regulates CPC-spindle interaction to ensure proper microtubule dynamics. J Cell Biol 194: 137-153

Pubmed: Author and Title

Google Scholar: Author Only Title Only Author and Title

Petrovská B, Cenklová V, Pochylová Z, Kourová H, Doskočilová A, Plíhal O, Binarová L, Binarová P (2012) Plant Aurora kinases play a role in maintenance of primary meristems and control of endoreduplication. New Phytol 193: 590-604

Pubmed: Author and Title

Google Scholar: Author Only Title Only Author and Title

Prusicki MA, Keizer EM, van Rosmalen RP, Komaki S, Seifert F, Müller K, Wijnker E, Fleck C, Schnittger A(2018) Live cell imaging of meiosis in Arabidopsis thaliana-a landmark system bioRxiv 446922

Pubmed: Author and Title

Google Scholar: Author Only Title Only Author and Title

Saze H, Kakutani T (2007) Heritable epigenetic mutation of a transposon-flanked Arabidopsis gene due to lack of the chromatinremodeling factor DDM1. EMBO J 26: 3641-3652

Pubmed: Author and Title

Google Scholar: Author Only Title Only Author and Title

Sessa F, Mapelli M, Ciferri C, Tarricone C, Areces LB, Schneider TR, Stukenberg PT, Musacchio A(2005) Mechanism of Aurora B activation by INCENP and inhibition by hesperadin. Mol Cell 18: 379-391

Pubmed: Author and Title

Google Scholar: Author Only Title Only Author and Title

Tang A, Gao K, Chu L, Zhang R, Yang J, Zheng J (2017) Aurora kinases: novel therapy targets in cancers. Oncotarget 8: 23937-23954 Pubmed: Author and Title

Google Scholar: Author Only Title Only Author and Title

Trivedi P, Stukenberg PT (2016) ACentromere-Signaling Network Underlies the Coordination among Mitotic Events. Trends Biochem Sci 41: 160-174

Pubmed: Author and Title 
Uren AG, Wong L, Pakusch M, Fowler KJ, Burrows FJ, Vaux DL, Choo KH (2000) Survivin and the inner centromere protein INCENP show similar cell-cycle localization and gene knockout phenotype. Curr Biol 10: 1319-1328

Pubmed: Author and Title

Google Scholar: Author Only Title Only Author and Title

Vader G, Kauw JJ, Medema RH, Lens SM (2006) Survivin mediates targeting of the chromosomal passenger complex to the centromere and midbody. EMBO Rep 7: 85-92

Pubmed: Author and Title

Google Scholar: Author Only Title Only Author and Title

Van Damme D, De Rybel B, Gudesblat G, Demidov D, Grunewald W, De Smet I, Houben A, Beeckman T, Russinova E (2011) Arabidopsis a Aurora kinases function in formative cell division plane orientation. Plant Cell 23: 4013-4024

Pubmed: Author and Title

Google Scholar: Author Only Title Only Author and Title

van der Horst A Lens SM (2014) Cell division: control of the chromosomal passenger complex in time and space. Chromosoma 123: 25-42

Pubmed: Author and Title

Google Scholar: Author Only Title Only Author and Title

van der Waal MS, Hengeveld RC, van der Horst A, Lens SM (2012) Cell division control by the Chromosomal Passenger Complex. Exp Cell Res 318: 1407-1420

Pubmed: Author and Title

Google Scholar: Author Only Title Only Author and Title

Weimer AK, Demidov D, Lermontova I, Beeckman T, Van Damme D (2016) Aurora Kinases Throughout Plant Development. Trends Plant Sci 21: 69-79

Pubmed: Author and Title

Google Scholar: Author Only Title Only Author and Title

Wijnker E, Schnittger A(2013) Control of the meiotic cell division program in plants. Plant Reprod 26: 143-158

Pubmed: Author and Title

Google Scholar: Author Only Title Only Author and Title

Xu Z, Ogawa H, Vagnarelli P, Bergmann JH, Hudson DF, Ruchaud S, Fukagawa T, Earnshaw WC, Samejima K (2009) INCENP-aurora B interactions modulate kinase activity and chromosome passenger complex localization. J Cell Biol 187: 637-653

Pubmed: Author and Title

Google Scholar: Author Only Title Only Author and Title

Yamanaka Y, Heike T, Kumada T, Shibata M, Takaoka Y, Kitano A, Shiraishi K, Kato T, Nagato M, Okawa K, Furushima K, Nakao K, Nakamura Y, Taketo MM, Aizawa S, Nakahata T (2008) Loss of Borealin/DasraB leads to defective cell proliferation, p53 accumulation and early embryonic lethality. Mech Dev 125: 441-450

Pubmed: Author and Title

Google Scholar: Author Only Title Only Author and Title

Zheng B, Chen X, McCormick S (2011) The anaphase-promoting complex is a dual integrator that regulates both MicroRNA-mediated transcriptional regulation of cyclin B1 and degradation of Cyclin B1 during Arabidopsis male gametophyte development. Plant Cell 23: 1033-1046

Pubmed: Author and Title

Google Scholar: Author Only Title Only Author and Title 